\title{
Coiling direction in Middle Miocene globorotaliids (Foraminiferida) - a case study in the Paratethys (Upper Silesia Basin, Poland)
}

\author{
Małgorzata GONERA ${ }^{1,2, \text { * }}$ \\ 1 The John Paul II Catholic University of Lublin, Off-Campus Faculty of Law and Social Sciences, Kwiatkowskiego 3A, \\ 37-450 Stalowa Wola, Poland \\ 2 Polish Academy of Sciences, Institute of Nature Conservation, Al. A. Mickiewicza 33, 31-120 Kraków, Poland
}

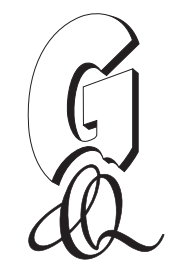

Gonera, M., 2018. Coiling direction in Middle Miocene globorotaliids (Foraminiferida) - a case study in the Paratethys (Upper Silesia Basin, Poland). Geological Quarterly, 62 (1): 155-171, doi: 10.7306/gq.1397

\begin{abstract}
The paper deals with sub-evaporite Badenian deposits (Middle Miocene, Paratethys) that display a sudden appearance of globorotaliid taxa showing preferences in the taxonomic set and coiling direction. An interval of sinistrally coiled Jenkinsella mayeri with proportionally coiled Globoconella bykovae is at the bottom of the studied sequence. It is followed by an interval of proportionally coiled Jenkinsella transsylvanica. Proportionally coiled Globoconella bykovae with a small number of proportionally coiled Jenkinsella transsylvanica are at the top of the Moravian (CPN 7) substage (Orbulina suturalis alias Lagenidae Zone). The sub-evaporite part of the Wielician (CPN 8) substage (Uvigerina costai alias Spiroplectammina Zone) began with a globorotaliid-barren interval (IIC biozone). It is followed by biozone IID displaying three globorotallid peaks amongst globorotallid-barren deposits. Only globoconellas are present in all these three events. Proportionally coiled Globoconella bykovae appeared first. It is followed by proportionally coiled Globoconella minoritesta and sinistrally coiled Globoconella bykovae at the end of the biozone IID. Coiling preferences of globorotaliids have been compared to changes in the hydrographic regime unfolding during the CPN 7 and CPN 8 in the studied area of the Paratethys. The study discovers that the coiling of globorotaliids responded selectively to the hydrographic changes. Globoconella bykovae is highly opportunistic and can tolerate considerable temperature changes. Specimens of this taxon persist to coil proportionally during the sub-evaporite Badenian, except for the shift to sinistral coiling just prior to the Wielician evaporites. Sinistrally coiled Jenkinsella mayeri is the most sensitive to hydrographic changes. This taxon retreated at the onset of the temperature drop during the mid-Moravian cryptic cooling. This cooling is marked by the new jenkinsellid occurrence - proportionally coiled Jenkinsella transsylvanica. Proportionally coiled Globoconella minoritesta is present in the middle of the IID globorotaliid peaks. The globorotaliid coiling data, presented in this paper, has been calibrated to the global stratigraphy. The integrated data (foraminifera, nannofossils, oxygen and carbon stable isotopes, radiometric measurements) supports the view that the CPN 7/CPN 8 boundary is coeval to the Langhian/Serravalian one. In the Polish part of the Carpathian Foredeep, the boundary runs within the Skawina Formation.
\end{abstract}

Key words: Middle Miocene, Paratethys, foraminifera, globorotaliid, coiling direction.

\section{INTRODUCTION}

Coiling direction is an easily traceable morphological aspect of trochospiral foraminifera. These organisms show a tendency to coil their test in a clockwise (dextral, right-handed) or counterclockwise (sinistral, left-handed) direction (Boltovskoy and Wright, 1976). The sinistral to dextral (L/R) ratio within the recent planktonic foraminifera population has been established, among others, for Neogloboquadrina pachyderma, Globorotalia crassaformis, Glob. hirsuta, Glob. truncatulinoides and Globigerina bulloides (Ericson et al., 1954; Jenkins, 1967; Thiede, 1971; Lidz, 1972; Malmgren and Kennett, 1976; Reynolds and Thunell, 1986). A relationship between coiling di-

\footnotetext{
*E-mail: malgorzatagonera@kul.lublin.pl Received: July 12, 2017; accepted: December 6, 2017; first published online: February 16, 2018
}

rection and surface water temperature has been discovered based on the spatial distribution of the foraminifera populations of the above species. The data demonstrate that different species may respond in opposite ways, however, coiling direction and the ambient water temperature in which the specimens lived are indeed correlative (Ericson et al., 1961; Boltovskoy, 1962, 1973; Bandy, 1972).

Bolli (1971) was the first who recognized the patterns in coiling direction and its use in stratigraphy, and was followed by many evolutionary and phylogenetic studies. It was assumed that random coiling persists during the early evolutionary stage of morphospecies. Stratigraphically younger representatives of these taxa can exhibit a preferred dominance in coiling direction. Those that attain left or right preferred coiling direction during their early evolution maintain it as a rule and may temporally switch in different coiling directions, but do never show random coiling. Within the stratigraphic range of a single morphospecies, distinct oscillations in coiling directions can occur (Bolli, 1971). 
Some taxa prefer either dextral or sinistral coiling and the achieved coiling preference remains the same worldwide during the stratigraphic range of the species. There are also taxa preferring either dextral or sinistral coiling, but the preferred coiling direction can change from one geographic region to another at the same time. For example, such two chiral forms of individual morphospecies (left-vs. right-coiled) are represented by Langhian Globorotalia praescitula described from lower versus higher latitudinal areas (Majewski, 2010; Foresi et al., 2011; respectively).

This case of coeval geographical differences in coiling preference within one morphospecies is apparently dependent on the temperature of water. Bandy's (1960) opinion that biochemical processes effected by temperature are responsible for the different ratio of coiling has been argued (Tolderlund and Bé, 1971; Brunner and Kroon, 1988; Kucera and Kennett, 2002 with references therein). The state of coiling, its biases and swings occurring in both recent species and fossil morphospecies, is a feature worth to observe regardless of the controlling causes like temperature and/or other environmental factors. As a simply measurable single-valued morphological aspect in trochospiral foraminifera shells, coiling direction has high potential in chronology and stratigraphy. Stratigraphic studies using the variation in coiling direction have been broadly carried out on planktonic foraminifera. These studies demonstrate the stratigraphic utility of coiling direction changes, although the patterns exhibited are complex (Nagappa, 1957; Vella, 1974; Kennett, 1976; Olsson, 1970; Hofker, 1972; Eisenach and Kelly, 2006 with references therein). Though, some particular biochemical processes responsible for coiling preferences are still under discussion, this morphological feature is extensively recognized, traced, mapped and applied in stratigraphy and palaeogeography (e.g., Ericson, 1959; Bolli, 1971; Kennett, 1976; Reynolds and Thunell, 1986; Naidu and Malmgren, 1996; Little et al., 1997; Winter and Pearson, 2001; Pfuhl and Shackleton, 2004; Eisenach and Kelly, 2006).

For the Middle Miocene of the Paratethys, the record of globorotaliid coiling direction within the Badenian deposits had been performed by Vašiček (1953) in the vicinity of Brno, Czech Republic (Fig. 1). As the sub-evaporite Badenian (Skawina Formation) globorotaliids of the Upper Silesia Basin was described by Gonera (2013), the material is revisited now concerning coiling direction of the specimens (Fig. 1 and Table 1). The present study discusses the globorotaliid coiling preferences of sub-evaporite Badenian morphospecies in these sediments. The globorotaliid taxonomy concept applied by Gonera (2013) has been sustained into this paper. The convention of viewing the spiral side of tests by Bolli (1950) were followed to determine the coiling direction of globorotaliid specimens.

A relationship between the coiling preference and hydrography was tested by the palaeoecological method. The planktonic assemblage is considered with respect to symbiont-bearing and temperature-related groups of planktonic taxa vs. the percentage of a non-spinose deep-pelagic group of taxa (globorotaliid) in the assemblage. Accordingly, the planktonic foraminifera morphospecies have been grouped into broadly defined categories based on ecologic criteria, i.a. by Bé and Tolderlund (1971), Bé (1977), Bé and Hutson (1977), Boltovskoy et al. (1996), Simstich et al. (2003), Schiebel and Hemleben (2005) and Wilke et al. (2009). The basic hydrography indices of environment are expressed in the studied material by the proportion of these categories (groups of taxa). A comparison of the globorotaliid coiling with

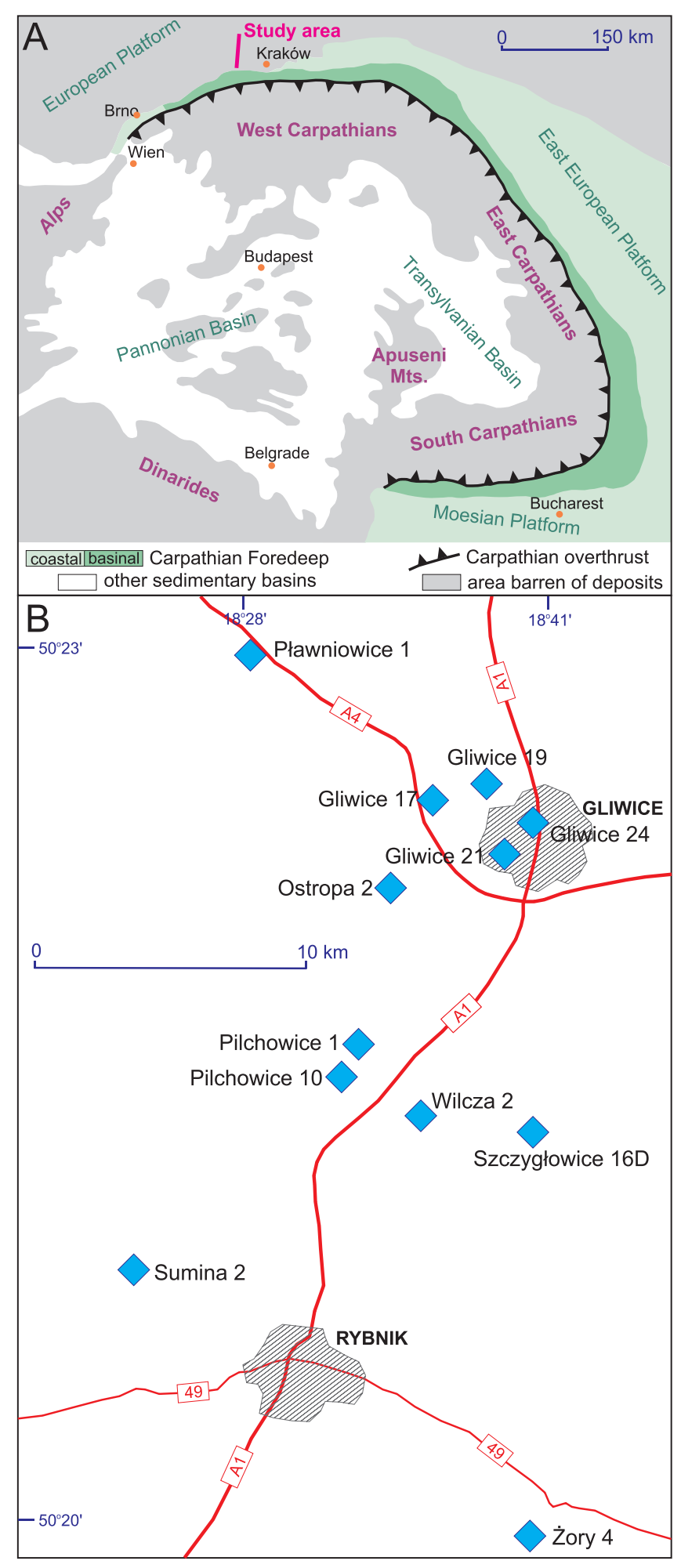

Fig. 1. Location map

A - distribution of Middle Miocene marine deposits in the Central Paratethys (modified after Seneš, 1971; Rögl, 1998); B - location of the studied boreholes.

the palaeohydrographic indices is provided and the usefulness of the globorotaliid coiling preferences for stratigraphy is demonstrated in this paper. 
Location of the studied sub-evaporite Badenian (Moravian and Wielician - pars) against the background of Central Paratethys stratigraphy

\begin{tabular}{|c|c|c|c|c|c|c|}
\hline \multicolumn{2}{|c|}{$\begin{array}{l}\text { Chronostratigraphy } \\
\text { (after Cicha et al., } \\
1975 \text { ) }\end{array}$} & \multicolumn{4}{|c|}{ Biozonation after: } & \multirow{2}{*}{$\begin{array}{c}\text { Lithostratigraphy units } \\
\text { mentioned in the text; after } \\
\text { Alexandrowicz et al. (1982), } \\
\text { Garlicki (1994) }\end{array}$} \\
\hline STAGE & SUBSTAGE & \multicolumn{2}{|c|}{$\begin{array}{c}\text { Cicha et al. (1975), Papp et al. (1978), } \\
\text { Rögl and Steininger (1984), } \\
\text { Steininger at al. (1985) }\end{array}$} & $\begin{array}{c}\text { Alexandrowicz } \\
(1963,1997)\end{array}$ & $\begin{array}{l}\text { Łuczkowska } \\
\quad(1964)\end{array}$ & \\
\hline \multirow{8}{*}{ 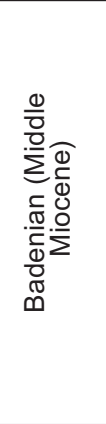 } & $\begin{array}{l}\text { KOSOVIAN } \\
\text { (CPN 9) }\end{array}$ & Velapertina Zone & $\begin{array}{l}\text { Bulimina-Bolivina } \\
\text { Zone }\end{array}$ & III B & $\begin{array}{l}\text { Hanzawaia } \\
\text { crassiseptata } \\
\text { Zone }\end{array}$ & \multirow{2}{*}{$\begin{array}{l}\text { not considered } \\
\text { in this paper }\end{array}$} \\
\hline & \multirow{4}{*}{$\begin{array}{l}\text { WIELICIAN } \\
\text { (CPN 8) }\end{array}$} & \multirow{4}{*}{$\begin{array}{l}\text { Globigerina druryi- } \\
\text { G. decoraperta Zone }\end{array}$} & \multirow{4}{*}{$\begin{array}{l}\text { Spiroplectammina } \\
\text { Zone }\end{array}$} & III A & $\begin{array}{l}\text { Neobulimina } \\
\text { longa Zone }\end{array}$ & \\
\hline & & & & \multicolumn{3}{|c|}{$\begin{array}{l}\text { Wielician salinity crisis deposits: Krzyżanowice Fm. } \\
\text { and Wieliczka Fm. }\end{array}$} \\
\hline & & & & IID & Uvigerina & \multirow{5}{*}{$\begin{array}{l}\text { Skawina Fm. } \\
\text { and Pińczów Fm. }\end{array}$} \\
\hline & & & & IIC & costai Zone & \\
\hline & \multirow{3}{*}{$\begin{array}{l}\text { MORAVIAN } \\
\text { (CPN 7) }\end{array}$} & \multirow{3}{*}{ Orbulina suturalis Zone } & \multirow{3}{*}{ Lagenidae Zone } & $\Pi \beta$ & \multirow{3}{*}{$\begin{array}{l}\text { Orbulina } \\
\text { suturalis Zone }\end{array}$} & \\
\hline & & & & IIB & & \\
\hline & & & & IIA & & \\
\hline
\end{tabular}

\section{GEOLOGICAL SETTING}

\section{MATERIAL AND METHODS}

The Upper Silesia Basin was located in the peripheral, NW part of the Carpathian Foredeep of the Paratethys during the Miocene (Oszczypko et al., 2006). The sub-Miocene basement in the Upper Silesia Basin is represented by Carboniferous and Triassic deposits, and the thickness of Miocene deposits ranges from 60 to $600 \mathrm{~m}$ (Alexandrowicz, 1963; Gonera, 2001). Patches of Lower Miocene brackish and freshwater deposits (Karpatian stage; e.g., Peryt et al., 2005) occur locally at the base. They are covered by the marine Badenian (Skawina Fm. in Table 1) with an average thickness of $66 \mathrm{~m}$ in the study area. The Skawina Fm. consists primarily of grey marly clays, and partly of sand or silty gravel, with intercalations of shelly and biodetrital limestones and marls (Alexandrowicz, 1997). The Badenian evaporites occur in part of the Upper Silesia Basin, generally attaining a thickness of a few tens of metres (Garlicki, 1979). In the studied boreholes, they are included in the Krzyżanowice Fm. (14.5-57.2 m thick). The well-known Wieliczka Fm., consisting of halite, appears only in the vicinity of Rybnik-Żory (Garlicki, 1979, 1994).

Biostratigraphic subdivision of the Skawina Fm. deposits is based mainly on foraminifers (Table 1). Considerable faunal shifts were observed in the sequence, which led to the use of particular assemblages as assemblage biozones (Alexandrowicz, 1963). Palaeoecological methods revealed that the stratigraphic succession of foraminiferal assemblages correlates well to palaeoenvironmental changes, and these biozones were established as ecozones (Gonera, 2001, 2013). Climate and climate-driven circulation patterns of palaeocurrents were found to be controlling the succession of these biozones (Szczechura, 1982; Gonera et al., 2000; Gonera, 2001, 2013; Bicchi et al., 2003; Gonera and Bukowski, 2012).

In spite of the various names used for the particular Badenian biozones within the Central Paratethys, they show consistency and can be readily traced throughout this area (e.g., Steininger et al., 1985; Popescu and Brotea, 1994; Cicha et al., 1998; Łuczkowska, 1998; Báldi, 2006; Doláková et al., 2014; Báldi et al., 2017).
Material for this paper comes from samples already analysed with regard to foraminiferal palaeoecology (Gonera, 2001), globorotaliid intervals (Gonera, 2013) and Globigerina bulloides coiling direction (Gonera et al., 2003). New samples from the Wilcza 2 borehole (Fig. 1) and one sample relatively rich in globorotaliids from the Wieliczka Salt Mine (sample no. 47 of Gonera et al., 2014) are also included. The sampled deposits are mudstones and marly claystones. Rock samples were prepared by the standard maceration procedure with $\mathrm{H}$-peroxide, and then washed on a $0.1 \mathrm{~mm}$ sieve. The residue (fraction $>0.1 \mathrm{~mm}$ ) was analysed stereomicroscopically.

Altogether, the studied material consists of 173 rock samples of the Skawina Formation deposits. Thirty-eight samples had only low percentage $(\leq 3.0 \%)$ of globorotaliids in the planktonic assemblage (see Gonera, 2001). As the first step of material filtering, these had been left out concerning coiling direction, but included into the hydrography database. For the remaining 135 rock samples of the Skawina Fm. deposits, globorotaliid taxa coiling ratios were presented (Table 1). Counting results for particular taxa are as follows: 112 Globoconella bykovae, 2 G. minoritesta, 59 Jenkinsella mayeri, and $56 \mathrm{~J}$. transsylvanica. A full list of all counts can be found in Appendix $1^{*}$. The number of tests $(>125 \mu \mathrm{m})$ examined for the taxa varied between 1 and 532 for Globoconella bykovae, 115-695 for G. minoritesta, 1-178 for Jenkinsella mayeri, and 3-364 for J. transsylvanica. In order to have a statistically significant database, referred here as counts, the coiling data of a particular taxon in the sample having $<41$ counts had been dropped out; it was usually case of low percentage $(\leq 3 \%)$ taxon in the planktonic assemblage.

Filtering of data with the two-step procedure resulted in a trustworthy database with a statistically significant number of coiling counts, suitable to obtain credible results. Only the following counts were considered: 91 counts for Globoconella bykovae, 2 for G. minoritesta, 37 for Jenkinsella mayeri and 43 for J. transsylvanica (Table 2). The results of the present study are based on this database. 
Percentage of sinistrally coiled globorotaliid specimens

\begin{tabular}{|c|c|c|c|c|c|c|}
\hline \multirow{2}{*}{ 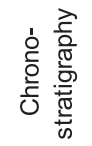 } & \multirow{2}{*}{\multicolumn{2}{|c|}{$\begin{array}{l}\text { Biozone and } \\
\text { globorotaliid } \\
\text { episodes in IID }\end{array}$}} & \multicolumn{2}{|c|}{ Globoconella } & \multicolumn{2}{|c|}{ Jenkinsella } \\
\hline & & & bykovae & minoritesta & mayeri & transsylvanica \\
\hline \multirow{5}{*}{$\begin{array}{l}\frac{z}{\leq} \\
\frac{0}{3} \\
\frac{w}{3}\end{array}$} & & $11 \mathrm{D}^{3}$ & $86.0 \pm 3.3[3]$ & & & \\
\hline & IID & $\| D^{2}$ & & $48.2 \pm 1.7[2]$ & & \\
\hline & & $\| D^{1}$ & $52.3 \pm 3.0[3]$ & & & \\
\hline & & & $57-532 / 80$ & & & \\
\hline & & IIC & & & & \\
\hline \multirow{6}{*}{ 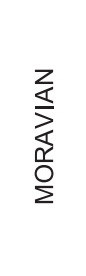 } & & $\| B$ & $49.8 \pm 2.8[29]$ & & & $49.7 \pm 3.5[12]$ \\
\hline & & & $55-344 / 236$ & & & $40-313 / 93$ \\
\hline & & IB & $47.5 \pm 4.9$ & & & $51.3 \pm 2.2[31]$ \\
\hline & & 15 & $56-326 / 209$ & & & $126-364 / 314$ \\
\hline & & IA & $50.8 \pm 3.0[51]$ & & $92.3 \pm 4.8[37]$ & \\
\hline & & & $40-423 / 303$ & & $43-182 / 128$ & \\
\hline
\end{tabular}

Bold - average and standard deviation of the sub-evaporite Badenian; in the brackets - number of samples; asterisk - data on coiling counts (minimal, maximal, median); dashed area - barren of taxa in the particular biozone

The percentage of cool-water versus warm-water planktonic foraminifera in the sample is considered as the epipelagic temperature signature. Globigerina bulloides and Turborotalita quinqueloba are regarded as cool-water epipelagic dwellers. Globoquadrina altispira, Globigerinoides quadrilobatus and Orbulina suturalis are assumed to be warm-water epipelagic dwellers. The third considered group comprises globorotaliids as deeper-pelagic non-spinose taxa. The set of other indices has been applied to tie the switches in globorotaliid coiling to hydrography changes known to happen during the deposition of the studied sequence. The percentage of globorotaliids has been used to assess basin depth history. As the indication of both bathymetry and shoreline distance, the P/B ratio was used (Murray, 1976). The database on oxygen and carbon stable isotopes submitted by Gonera and Bukowski (2012) are reconsidered now as the tracers of temperature and carbon cycling, respectively.

\section{RESULTS}

\section{MORAVIAN}

Globorotaliids of biozone IIA are represented by Globoconella bykovae and Jenkinsella mayeri. Out of the total number of 60 examined rock samples, only one sample contains $<3 \%$ of globorotaliids among planktonic foraminifera (Gliwice $21,233.5 \mathrm{~m}$ ). According to the first step of the material selection, this sample has been omitted.

The percentage of $G$. bykovae in the planktonic assemblage ranges from $0.3 \%$ (Gliwice $21,267.6 \mathrm{~m}$ ) to $89.5 \%$
(Pilchowice 1, $320.0 \mathrm{~m}$ ) with the mean value of $33.5 \pm 26.2 \%$ (Fig. 2). Eight samples of insufficient G. bykovae coiling counts ( $\leq 40$ specimens) recorded in the Gliwice 21 borehole have been omitted in sinistrality counts of the taxon. For the remaining 51 rock samples the median of sinistrally coiled specimens is $50.9 \%$ (Fig. 2 and Table 2), the percentage of G. bykovae among planktonic foraminifers varies from 1.8\% (Gliwice 19, $270.0 \mathrm{~m}$ ) to $89.5 \%$ (Pilchowice $1,320.0 \mathrm{~m}$ ), and the average value is $38.1 \pm 25.1 \%$.

In the analysed 59 samples, the percentage of J. mayeri in the planktonic foraminiferal assemblage fluctuates from $0.5 \%$ (Pilchowice 10,615.0 m) to $28.8 \%$ (Gliwice 21, $224.3 \mathrm{~m}$ ) and the average is $9.1 \pm 7.2 \%$ (Fig. 2). The number of insufficient coiling counts ( $\leq 40$ specimens) is 22 ; most of them in the Gliwice 21 (9 samples) and Gliwice 17 (6 samples) boreholes. The median of sinistrally coiled specimens is $92.5 \%$ in 37 rock samples (Fig. 2 and Table 2): the percentage of $\mathrm{J}$. mayeri in planktonic foraminifera ranges from 2.0\% (Gliwice 19, $289.0 \mathrm{~m}$; Pilchowice 10, 605.0 m) to $28.8 \%$ (Gliwice 21, $224.3 \mathrm{~m}$ ); average value is $12.0 \pm 7.3 \%$.

Biozone IIB contains two globorotaliid taxa of Globoconella bykovae and Jenkinsella transsylvanica. Out of the total number of examined rock samples (33) only one contained $<3 \%$ of globorotaliids among the planktonic foraminifera (Gliwice 21, $204.0 \mathrm{~m}$ ). In the remain 32 samples $\mathrm{G}$. bykovae occurs only in 16 and $J$. transsylvanica in all of rock samples (Appendix 1).

The percentage of $G$. bykovae in planktonic foraminifera varies from $0.5 \%$ (Pilchowice $10,575.0 \mathrm{~m}$ ) to $45.0 \%$ (Gliwice $21,202.2 \mathrm{~m}$ ) with the mean value of $6.8 \pm 11.8 \%$ (Fig. 2). Only four samples remain reliable concerning coiling data according to the applied method, and the median of sinistrally coiled 


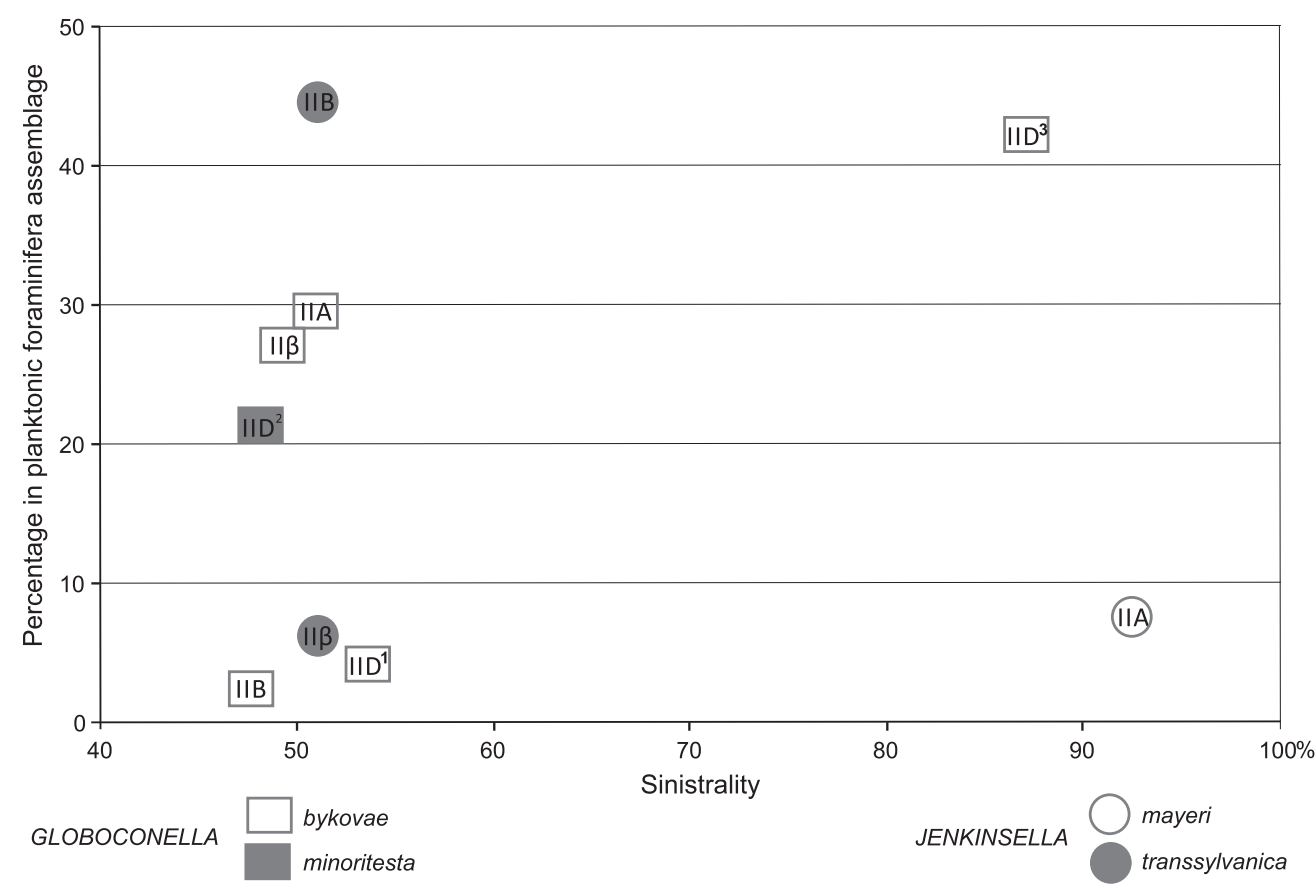

Fig. 2. Globorotaliid abundance (median) vs. sinistrality within Moravian biozones (IIA, IIB, II $\beta$ ) and globorotaliid episodes (IID ${ }^{1}$, IID $^{2}$, IID ${ }^{3}$ ) during the Wielician IID biozone

Sinistrality $47-53 \%$ is implemented as proportional coiling

G. bykovae specimens is $47.7 \%$ (Fig. 2 and Table 2). The percentage of $\mathrm{G}$. bykovae in the planktonic foraminiferal assemblage ranges from $0.7 \%$ (Pławniowice 1, $142.0 \mathrm{~m}$ ) to $45.0 \%$ (Gliwice 21, $202.2 \mathrm{~m}$ ); average value is $20.2 \pm 19.4 \%$.

In 32 samples of biozone IIB, J. transsylvanica accounts for from $2.5 \%$ of (Gliwice 21, $202.2 \mathrm{~m}$ ) to $95.2 \%$ (Pilchowice 10, $565.0 \mathrm{~m}$ ) among planktonic foraminifera, with an average value of $47.0 \pm 23.5 \%$ (Fig. 2). There are insufficient coiling counts (<40 specimens) in one sample (Gliwice 21, $202.2 \mathrm{~m}$ ). The median of sinistrally coiled specimens in the other 31 samples is 51.1\% (Fig. 2 and Table 2), and the J. transsylvanica percentage among planktonic foraminifera varies from $12.5 \%$ (Gliwice $19,220.0 \mathrm{~m}$ ) to $95.2 \%$ (Pilchowice $10,565.0 \mathrm{~m}$ ) with a mean value of $48.4 \pm 22.4 \%$.

Biozone II $\beta$ contains two globorotaliid taxa: Globoconella bykovae and Jenkinsella transsylvanica. Among all the examined rock samples, two samples contain the not required number of globorotaliids $(\leq 3 \%)$ in the planktonic foraminiferal assemblage (Gliwice 19, $181.2 \mathrm{~m}$; Żory 4, $105.0 \mathrm{~m}$ ). G. bykovae is present in 35 samples more. J. transsylvanica is found in 26 of them (Appendix 1). The percentages G. bykovae among planktonic foraminifera ranges from $2.4 \%$ (Pławniowice 1, $139.0 \mathrm{~m}$ ) to $63.6 \%$ (Pilchowice $10,554.0 \mathrm{~m}$ ) with the mean value 26.8 $\pm 18.1 \%$ (Fig. 2). In six samples, the number of coiling counts is $\leq 40$ specimens. In the other 29 samples, the median of sinistrally coiled G. bykovae specimens is $49.4 \%$ (Fig. 2 and Table 2). The percentage of $G$. bykovae among planktonic foraminifera of these 29 samples varies from $3.4 \%$ (Gliwice 19 , $179.0 \mathrm{~m}$ ) to $63.6 \%$ (Pilchowice $10,554.0 \mathrm{~m}$ ) with the mean value at $28.9 \pm 17.4 \%$. The percentage of $\mathrm{J}$. transsylvanica ranges from $0.7 \%$ (Wilcza 2, $96.0 \mathrm{~m}$ ) to $69.0 \%$ (Pławniowice 1 , $139.0 \mathrm{~m}$ ) with the mean value $17.1 \pm 21.0 \%$ (Fig. 2). In the samples of this biozone the number of samples displaying insuffi- cient coiling counts is 14 and only 12 samples are considered reliable coiling data. The median of sinistrally coiled specimens is $51.0 \%$ (Fig. 2 and Table 2), and the percentage of $J$. transsylvanica in these planktonic foraminiferal assemblage ranges from 5.6\% (Gliwice 24, $163.0 \mathrm{~m}$ ) to $69.0 \%$ (Pławniowice $1,139.0 \mathrm{~m}$ ) with the average $33.0 \pm 21.9 \%$.

\section{WIELICIAN}

The IIC biozone is barren of globorotaliids ( 12 rock samples were checked). Globorotaliids are absent also in samples of the IID biozone, except for globorotaliids quantitatively significant occurrence (peaks) traced within few separated samples in the studied II D biozone material. Altogether, 30 rock samples of the IID biozone comprising peaks in 8 samples were checked; single Globoconella bykovae specimens in sample $81.0 \mathrm{~m}$ of the Wilcza 2 borehole is omitted from the globorotaliid coiling counting. The peaks comprise Globoconella bykovae in six samples and Globoconella minoritesta in two samples (Appendix 1).

There are different coiling preferences of $G$. bykovae present in the studied six samples. In three of them (Pławniowice 1, 133.0 and $130.0 \mathrm{~m}$; Gliwice 19, $173.5 \mathrm{~m}$ ) the mean value of sinistrally coiled specimens is $52.3 \pm 3.0 \%$ with the median $53.6 \%$. The percentage of $G$. bykovae in the planktonic assemblage is from $3.5 \%$ (Gliwice $19,173.5 \mathrm{~m}$ ) to $11.7 \%$ (Pławniowice $1,130.0 \mathrm{~m}$ ) with the mean value $6.5 \pm 4.5 \%$. In the other three samples of the $G$. bykovae quantitative peaks (Żory 4, $55.0 \mathrm{~m}$; Sumina 2, $286.0 \mathrm{~m}$; KSW sample no. 47) the mean value of sinistrally coiled specimens is $86.0 \pm 3.3 \%$ with the median $87.1 \%$. The percentage of $G$. bykovae in the planktonic assemblage of these samples range from $12.3 \%$ (KSW sample no. 
47 ) to $66.7 \%$ (Żory $4,55.0 \mathrm{~m}$ ) with the mean value 40.4 $\pm 27.2 \%$. In the two peaks of the Globoconella minoritesta (Bielszowice 7, $83.0 \mathrm{~m}$; Gliwice 19, $172.0 \mathrm{~m}$ ) the mean value of sinistrally coiled specimens is $48.2 \pm 1.7 \%$. The percentage of G. minoritesta in the planktonic assemblage is $6.6 \%$ (Bielszowice $7,83.0 \mathrm{~m}$ ) and $35.8 \%$ (Gliwice $19,172.0 \mathrm{~m}$ ) with the mean value $21.2 \pm 20.6 \%$.

The stratigraphic order of the globorotaliid events is shown in Figure 2 and Table 2. In the Gliwice 19 borehole, proportionally coiled $G$. bykovae (IID ${ }^{1}$ ) in sample $173.5 \mathrm{~m}$ is followed by proportionally coiled G. minoritesta (IID ${ }^{2}$ ) in sample 172.0 m of this borehole (Appendix 1, Table 2 and Fig. 2). The dominance of sinistrally coiled Globoconella bykovae $\left(\right.$ IID $^{3}$ ) is recorded in the Sumina 2 (sample $286.0 \mathrm{~m}$ ) and Żory 4 (sample $55.0 \mathrm{~m}$ ) boreholes, and in the Salt Breccia Member of the Wieliczka deposit (xenolith sample no. 47). In the presently studied material, sinistrally coiled Globoconella bykovae event $\left(\right.$ IID $\left.^{3}\right)$ is not traced in the same borehole jointly with any of the events mentioned above (Appendix 1). As this event is observed just few centimetres below the evaporites of the Krzyżanowice Fm. in the Sumina 2 borehole, this of the Wielician globorotaliid events is positioned as the youngest globorotaliid-bearing layer.

\section{COMPARISON AND DISCUSSION}

\section{COMPARISON OF COILING DATA WITH COEXISTING GLOBOROTALIID MORPHOSPECIES}

The taxa names of globorotaliids Jenkinsella transsylvanica, Globoconella bykovae and G. minoritesta are in use only in the Paratethys. These taxa names do not have counterparts even in the adjoining part of the Mediterranean Basin connected with the Paratethys through seaways (i.a. Rögl, 1998). Only Globoconella bykovae has been described apart from the Paratethyan area (e.g., Saito and Maiya, 1973; Fujiwara et al., 2008). This generates a significant obstacle to perform comparisons between the globorotaliid coiling data presented herein and non-Paratethys data. Comparison of coiling directions with non-Paratethys data is possible only if we assume that the Globoconella bykovae, Jenkinsella transsylvanica and Globoconella minoritesta are morphotypes of some of the globally known taxa.

The direct comparison of the coiling mode can be undertaken concerning Jenkinsella mayeri Cushman, Ellisor, 1939 and its synonymous Globorotalia siakensis LeRoy, 1939 (after Bolli and Saunders, 1982). A distinct change from proportional to sinistral J. mayeri occurred in the Miocene Zone N8 (notation after Blow, 1969). The sinistrality persisted until the extinction of the taxon at the end of the Middle Miocene (Winter and Pearson, 2001). In the studied Paratethys sediments, J. mayeri specimens are sinistrally coiled and abundant within the IIA biozone. They disappear at the base of the IIB biozone (Tables 1, 2 and Fig. 2). As Orbulina suturalis is present, thus the studied sediments can be not older than N9 (notation after Blow, 1969). The stratigraphic range of J. mayeri with sinistral coiling in the Upper Silesia Basin is consistent with data from Winter and Pearson (2001). Jenkinsella mayeri specimens show average percentages of $\sim 9 \%$ (max. $28.8 \%$ ) within the IIA biozone, which has been used as this taxon acme within the CPN 7 (Table 1). This Paratethyan interval correlates well with N9 sinistrally coiled $J$. siakensis acme $A_{b}$ in the Mediterranean sediments (Abdul Aziz et al., 2008; Hüsing et al., 2010). According to Hilgen et al. (2009), this acme ends at the top of N9; how- ever, the data on coiling mode has not been provided so far. The $A_{b}$ Paragloborotalia (J.) siakensis is shown also by Foresi et al. (2011) in the Langhian GSSP, but the specimens are randomly coiled therein, without exact counts of coiling directions.

Based on the resemblance of morphology, Globoconella bykovae can be considered as the morphotypes of either Fohsella peripheroronda or Globorotalia praescitula (Gonera, 2013). Both are globally known taxa and common components of the Mediterranean Middle Miocene planktonic foraminiferal assemblage (laccarino, 1985). In the studied material, Globoconella bykovae specimens are proportionally coiled up to the $I I D^{3}$ influx - only in this exceptional event the specimens display a strong bias to sinistrality (Fig. 2 and Table 2). Within the fohsellids, the proportions of coiling direction have been documented from their appearance during early phylogeny, from long-ranging Fohsella peripheroronda to $F$. peripheroacuta, all with strong preference for sinistral coiling (Bolli, 1950). This bias to sinistrality in fohsellids was raised by Eisenach and Kelly (2006) in the Serravalian M8 biozone (notation after Berggren et al., 1995). The fohsellids younger than Fohsella peripheroronda are not displayed in the Mediterranean Miocene (Cita and Blow, 1969; laccarino, 1985; Hilgen et al., 2009; Foresi et al., 2011). The presence of Fohsella cf. peripheroacuta is mentioned by Lirer and laccarino (2005), yet with no coiling data. In the Paratethys, F. peripheroacuta is shown by Rögl (1985) as a Wielician globorotaliid, but data on coiling direction is not given. Another possibility is that $G$. bykovae specimens of the studied Paratethys sediments are morphotypes of Globorotalia praescitula. The proportionally coiled Globoconella bykovae specimens display the same coiling mode as Globorotalia praescitula described from the Mediterranean Langhian by Foresi et al. (2011). Sinistrally coiled Globoconella bykovae (IID ${ }^{3}$ event) cannot be compared to the Mediterranean globorotaliids at present, as the lack of advanced data on coiling mode of the Mediterranean F. peripheroronda and G. praescitula. Because of the current lack of data, the documented coiling patterns in the study area (basinal part of the Carpathian Foredeep in the Upper Silesia Basin) cannot to be compared to that in other areas of the Paratethys.

The specimens of J. transsylvanica and G. minoritesta demonstrate morphological resemblance to well-known globorotaliids: Globorotalia challengeri Srinivasan and Kennett 1982 and Globorotalia miotumida Jenkins 1960, respectively. Until now, there have been no systematic studies on the coiling preferences, just occasionally mentioned in the literature (e.g., Scott et al., 1990). As in the Mediterranean Miocene sediments, none of the mentioned Paratethyan taxa has been shown. Therefore, until an advanced study on the taxonomy of these taxa is written, the comparison of coiling to global data in the present work has its limitations. However, the mentioned Paratethyan globorotaliids confirm Bolli's (1971) opinion on a proportional coiling pattern at the initial stage of phylogeny of the species at its stratigraphic appearance.

\section{GLOBOROTALIID COILING PREFERENCES VERSUS BASIN HYDROGRAPHY INDICES}

Quantitative data on the hydrographic indices of the analysed samples within the studied Badenian are displayed in Table 3. The number of samples used to evaluate hydrography overcomes by $\sim 28 \%$ these used to globorotaliid coiling counts (compare the data in Tables 2 and 3).

Sinistrally coiled Jenkinsella mayeri (J. mayeri ${ }^{\text {SINI }}$ ) occurs in the studied sediments within biozone IIA. The specimens disappear at the base of biozone IIB, and they do not occur in the 
Hydrographic indices (average and standard deviation) of the sub-evaporite Badenian biozones

\begin{tabular}{|c|c|c|c|c|c|c|c|c|c|}
\hline \multirow{2}{*}{$\begin{array}{l}\stackrel{0}{\circ} \\
\stackrel{\circ}{\circ}\end{array}$} & \multirow{2}{*}{\multicolumn{3}{|c|}{$\mathrm{P} / \mathrm{B}$ ratio }} & \multicolumn{4}{|c|}{ Percentage of symbiont bearing globigerinina } & \multirow{2}{*}{\multicolumn{2}{|c|}{$\begin{array}{l}\text { Percentage of } \\
\text { globorotaliids }\end{array}$}} \\
\hline & & & & \multicolumn{2}{|c|}{ Cool-water * } & \multicolumn{2}{|c|}{ Warm-water ** } & & \\
\hline \multirow{3}{*}{ IID [30] } & $\overline{\mathbb{N}}$ & $111 \mathrm{D}^{3}$ & $23.1 \pm 12.3[3]$ & \multirow{3}{*}{ 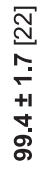 } & $52.5 \pm 26.7[3]$ & \multirow{3}{*}{$\begin{array}{l}\bar{m} \\
\stackrel{\rho}{\mathbf{N}} \\
+1 \\
\stackrel{+}{-}\end{array}$} & $7.1 \pm 1.7[2]$ & \multirow{3}{*}{$\begin{array}{l}\overline{\underline{V}} \\
\overline{0} \\
+1 \\
\text { +1 } \\
0\end{array}$} & $40.4 \pm 27.2[3]$ \\
\hline & $\bar{m}$ & $11 \mathrm{D}^{2}$ & $29.0 \pm 13.0[2]$ & & $73.5 \pm 15.9[2]$ & & $5.4 \pm 4.7[2]$ & & $21.2 \pm 20.6[2]$ \\
\hline & है & \begin{tabular}{|l|l|}
1 \\
\end{tabular} & $36.0 \pm 15.9[3]$ & & $43.4 \pm 40.2[3]$ & & $46.8 \pm 35.2[3]$ & & $6.5 \pm 4.5[3]$ \\
\hline IIC [12] & \multicolumn{3}{|c|}{$61.7 \pm 29.4[12]$} & \multicolumn{2}{|c|}{$97.0 \pm 3.9[12]$} & \multicolumn{2}{|c|}{$3.3 \pm 4.0[7]$} & \multicolumn{2}{|r|}{$0.0[12]$} \\
\hline$\| \beta[38]$ & \multicolumn{3}{|c|}{$61.5 \pm 19.9[38]$} & \multicolumn{2}{|c|}{$25.3 \pm 28.1[37]$} & \multicolumn{2}{|c|}{$36.0 \pm 25.0[37]$} & \multicolumn{2}{|c|}{$37.4 \pm 25.9[37]$} \\
\hline IIB [33] & \multicolumn{3}{|c|}{$66.7 \pm 12.6[33]$} & \multicolumn{2}{|c|}{$15.6 \pm 15.7[33]$} & \multicolumn{2}{|c|}{$27.6 \pm 15.8[32]$} & \multicolumn{2}{|c|}{$49.0 \pm 22.5[33]$} \\
\hline IIA [60] & \multicolumn{3}{|c|}{$54.2 \pm 12.5[60]$} & \multicolumn{2}{|c|}{$28.4 \pm 18.3[59]$} & \multicolumn{2}{|c|}{$25.4 \pm 16.5[60]$} & \multicolumn{2}{|c|}{$41.9 \pm 25.2[60]$} \\
\hline
\end{tabular}

In the bracket - number of samples considered for particular biozones; * - means Globigerina bulloides and Turborotalita quinqueloba; ** - means Globoquadrina altispira, Globigerinoides quadrilobatus and Orbulina suturalis

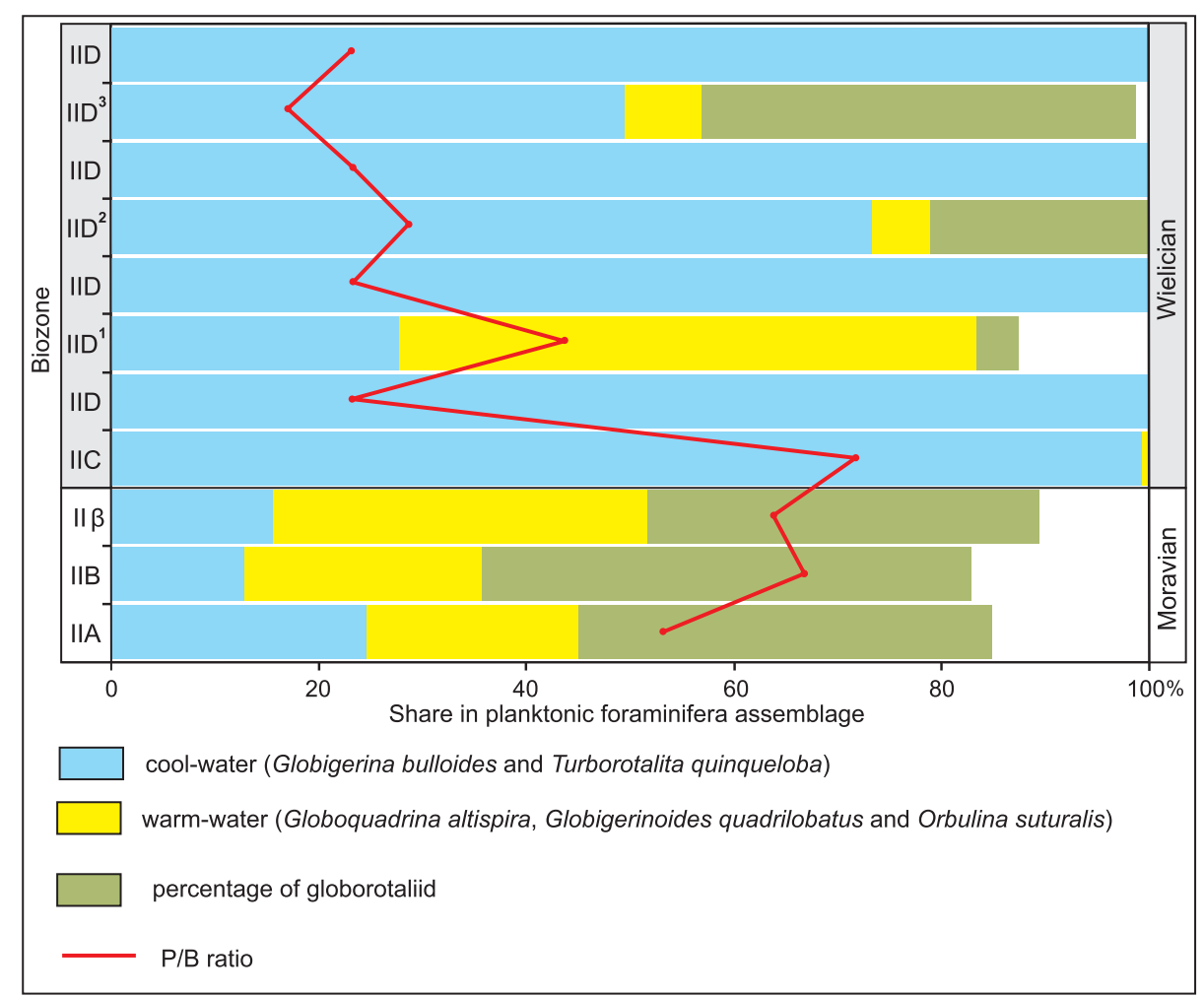

Fig. 3. Planktonic foraminifera eco-groups vs. P/B ratio (median) of the sub-evaporite Badenian in the study area

1 - cool-water (Globigerina bulloides and Turborotalita quinqueloba), 2 - warm-water (Globoquadrina altispira, Globigerinoides quadrilobatus and Orbulina suturalis),

$$
3 \text { - percentage of globorotaliids, } 4 \text { - P/B ratio }
$$


upper part of the Skawina Fm. (Gonera, 2013). At the IIA/IIB boundary, the P/B ratio increases by $\sim 14 \%$ (Fig. 3), while the percentage of warm-water planktonic forms in the plankton foraminiferal assemblage remains similar (only $\sim 3 \%$ increase). These two biozones show a faunal shift regarding the decrease of cool-water taxa $(\sim 12 \%)$ and an increase of globorotaliids $(\sim 8 \%)$. This results in a relative decrease of Globigerina bulloides and Turborotalita quinqueloba percentage in planktonic foraminiferal assemblage, while the percentage of deepest-dwelling globorotaliid planktonic forms increases.

The change at the IIA/IIB boundary is very pronounced regarding oxygen and carbon stable isotopes (Table 4). There is a $\delta^{18} \mathrm{O}$ increase in both benthic and planktonic foraminifers and a simultaneous decrease in $\Delta \delta^{18} \mathrm{O}$ between pelagic and bottom dwellers in the basin (Fig. 4). The palaeoenvironmental change at the IIA/IIB boundary has been already inferred by Gonera (2013) as the imprint of the mid-Moravian cryptic cooling in the study area. At the IIA/IIB boundary, $\delta^{13} \mathrm{C}$ shows a remarkable shift (Fig. 4). There is a slight decrease in $\delta^{13} \mathrm{C}$ within benthic foraminifera tests and a pronounced increase within planktonic foraminifera tests $(\sim 0.05$ and $\sim 0.41 \%$, respectively). Particularly pronounced is the $\Delta \delta^{13} \mathrm{C}$ of the IIB biozone comparing to that of the IIA biozone ( 0.76 and $0.30 \%$, respectively). These measurements allow assuming that nutrients supply increased and the productivity intensified due to IIB cooling, thus phytoplankton drained isotopically lighter carbon causing ${ }^{13} \mathrm{C}$ uplift in planktonic foraminifera tests. The process was very intense, as inferred based on the comparison of Globigerina bulloides ${ }^{13} \mathrm{C}$ contents between the biozones of IIA and IIB. The decay of phytodetritus at the sea floor enhanced the bottom waters in ${ }^{12} \mathrm{C}$. Due to the incorporation of the lighter carbon, the Uvigerina tests were richer in ${ }^{12} \mathrm{C}$ than the uvigerinas of the IIA biozone (Fig. 5). Biozone IIB displays a significantly different state of the considered hydrographic indices compared to those of biozone IIA. These new conditions eliminated J. mayeri ${ }^{\text {SINI }}$ from the environment.

The IIB sediments contain another Jenkinsella species. It is proportionally coiled J. transsylvanica (J. transsylvanica PROP). The favourable habitat conditions of this period induced an acme of the morphospecies. Upward, within the $I \beta$ biozone, strong reduction in the J. transsylvanica content (still proportionally coiled) occurs. In this youngest biozone of the Moravian substage (CPN 7) there is a slight drop in the P/B ratio compared to the previous IIB biozone (Fig. 3 and Table 3 ). While the percentages of cool-water taxa remain similar (only $\sim 3 \%$ increase) these two biozones differ as regards warm-water ones $(\sim 13 \%$ increase $)$ and the globorotaliid content $(\sim 10 \%$ decrease). At the first sight, these foraminiferal indices of the $\| \beta$ and IIA biozones are similar, but there is a pronounced difference in the oxygen and carbon stable isotope values. The $\delta^{18} \mathrm{O}$ is $0.72 \%$ higher in planktonic foraminifers and $0.9 \%$ higher in Uvigerina. Thus, the basin temperature during the $\| \beta$ biozone was much cooler than during IIA. On the other hand, the surface temperature of II $\beta$ was warmer than of IIB, but the bottom temperature was even cooler than of IIB (Fig. 5). Dissimilarity between IIA and II $\beta$ is also observed as regards $\delta^{13} \mathrm{C}$. During the final Moravian biozone (II $\beta), \delta^{13} \mathrm{C}$ in both bottom and pelagic waters was higher than during IIA: 0.09 and $0.56 \%$, respectively (Fig. 5). Both $\| \beta$ planktonic and benthic tests incorporate the carbon reached in ${ }^{13} \mathrm{C}$. The change to these warmer and nutrient-poor pelagic waters was the feature discriminating $\mathrm{J}$. transsylvanica ${ }^{\mathrm{PROP}}$ from the basin, as only low amounts are still present in some $\| \beta$ samples. As globorotaliids, this taxon retreated from the studied sediments due to the definitive disappearance of the Moravian biotope at the base of the Wielician IIC biozone in the study area of the Paratethys (Alexandrowicz, 1963; Gonera, 2001).

Globoconella bykovae is a relatively common and long-lasting globorotaliid in the study area. The taxon is proportionally coiled at the beginning of biozone IIA and persists in this coiling pattern during the Moravian biozones. This coiling pattern was kept unchanged in spite of the changes in basin hydrography indices, even when the number of taxon's individuals is low and tentatively diminishes during biozone IIB. As all the globorotaliids, G. bykovae disappears in the Wielician biozones, except for a single specimen in the studied samples. At the beginning of the Wielician, the continuous presence of globorotaliids in the sediment ended. After the Moravian/Wielician boundary, there were solely episodic influxes of waters carrying globorotaliids into the study area. These influxes carried only globoconellas.

Isotopic composition of planktonic (Globigerina bulloides) and benthic (Uvigerina spp.) foraminifera (mean value and standard deviation) in the sub-evaporite Badenian (database after Gonera and Bukowski, 2012)

\begin{tabular}{|c|c|c|c|c|c|c|c|c|c|c|c|c|}
\hline \multirow{2}{*}{$\begin{array}{c}\text { BIOZONE } \\
{[+]}\end{array}$} & \multicolumn{6}{|c|}{$\delta^{18} \mathrm{O}[\% \circ \mathrm{V}-\mathrm{PDB}]$} & \multicolumn{6}{|c|}{$\delta^{13} \mathrm{C}[\% \circ \mathrm{V}-\mathrm{PDB}]$} \\
\hline & \multicolumn{3}{|c|}{ Uvigerina spp. $\left[{ }^{*}\right]$} & \multicolumn{3}{|c|}{ Globigerina bulloides [^] } & \multicolumn{3}{|c|}{ Uvigerina spp. $\left[{ }^{*}\right]$} & \multicolumn{3}{|c|}{ Globigerina bulloides [*] } \\
\hline \multirow{3}{*}{ IID [8] } & \multirow{3}{*}{ 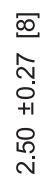 } & $11 \mathrm{D}^{3}$ & No data & \multirow{3}{*}{$\begin{array}{l}\tilde{\Omega} \\
\bar{N} \\
\stackrel{0}{0} \\
+1 \\
\stackrel{0}{0} \\
\stackrel{0}{\Gamma}\end{array}$} & $111 D^{3}$ & No data & \multirow{3}{*}{$\begin{array}{l}\bar{\infty} \\
0 \\
0 \\
0 \\
+1 \\
\infty \\
\infty \\
0 \\
0\end{array}$} & $11 \mathrm{D}^{3}$ & No data & \multirow{3}{*}{ 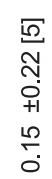 } & \multirow{2}{*}{\begin{tabular}{|l|}
$I I D^{3}$ \\
$I I D^{2}$ \\
\end{tabular}} & No data \\
\hline & & \multicolumn{2}{|c|}{$\| \mathrm{ID}^{2}$} & & $\mid I D^{2}$ & No data & & \begin{tabular}{|l|}
$I \mathrm{D}^{2}$ \\
\end{tabular} & No data & & & No data \\
\hline & & $I I D^{1}$ & $1.35 \pm 0.04[2]$ & & $\mid \mathrm{IID}^{1}$ & $-0.28 \pm 0.64[2]$ & & $\mathrm{IID}^{1}$ & $0.18 \pm 0.20[2]$ & & \begin{tabular}{|l|} 
IID $^{1}$ \\
\end{tabular} & $0.46 \pm 0.01[2]$ \\
\hline IIC [8] & \multicolumn{3}{|c|}{$2.60 \pm 0.19[7]$} & \multicolumn{3}{|c|}{$2.00 \pm 0.22[7]$} & \multicolumn{3}{|c|}{$0.07 \pm 0.14[7]$} & \multicolumn{3}{|c|}{$0.64 \pm 0.37[7]$} \\
\hline$\| \beta[13]$ & \multicolumn{3}{|c|}{$1.64 \pm 0.35[11]$} & \multicolumn{3}{|c|}{$0.16 \pm 0.88[10]$} & \multicolumn{3}{|c|}{$0.09 \pm 0.17[11]$} & \multicolumn{3}{|c|}{$0.58 \pm 0.44[10]$} \\
\hline IIB [11] & \multicolumn{3}{|c|}{$1.41 \pm 0.27[11]$} & \multicolumn{3}{|c|}{$0.32 \pm 0.54$ [9] } & \multicolumn{3}{|c|}{$-0.06 \pm 0.13[11]$} & \multicolumn{3}{|c|}{$0.71 \pm 0.41[9]$} \\
\hline IIA [15] & \multicolumn{3}{|c|}{$0.92 \pm 0.19[14]$} & \multicolumn{3}{|c|}{$-0.58 \pm 0.31[9]$} & \multicolumn{3}{|c|}{$0.08 \pm 0.34[14]$} & \multicolumn{3}{|c|}{$0.43 \pm 0.26[9]$} \\
\hline
\end{tabular}

$[+]$ number of rock samples analysed in regard to oxygen and carbon stable isotopes, $\left.{ }^{*}\right]$ number of $\delta^{18} \mathrm{O}$ and $\delta^{13} \mathrm{C}$ data 

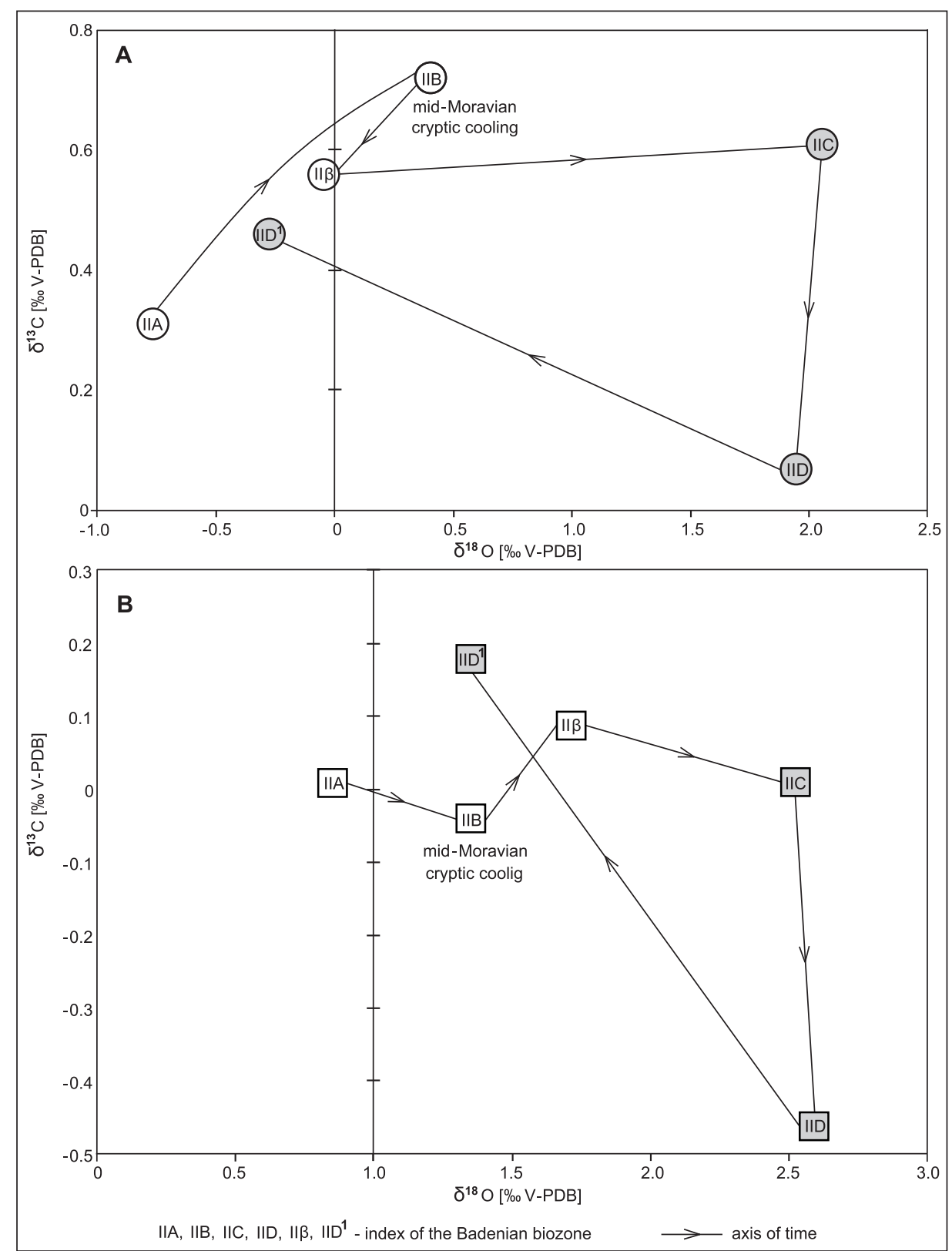

Fig. 4. Foraminiferal oxygen vs. carbon stable isotope values (median) of the sub-evaporite Badenian

A - plot of Globigerina bulloides (planktonic); B - plot of Uvigerina spp. (benthic); for more data see Table 4

The hydrographic features, which eliminated the globorotaliids, are described below.

The P/B ratio slightly increased at the II $\beta / I C$ boundary and, simultaneously, the polytypic (rich in taxa) planktonic foraminiferal assemblage has been substituted by a monotypic (poor in taxa) population. A bloom of cool-water Globigerina bulloides (Table 3 and Fig. 3) can be reconstructed. The II $\beta / I I C$ boundary is very pronounced in regard to the oxygen stable isotope (Table 4 and Fig. 4). There is a $\delta^{18} \mathrm{O}$ increase in both planktonic and benthic foraminifera: 2.1 and $0.8 \%$, respectively (Fig. 5). Noteworthy is the continuous increase in $\delta^{18} \mathrm{O}$ throughout the Moravian. Nevertheless, in pelagic realms the decrease happened in the warmer interval of the $\| \beta$ biozone (Fig. 5). Strong cooling is reflected in the pelagic assemblage of biozone
IIC, and, combined with decreasing $\Delta \delta^{18} \mathrm{O}$, must be the result of strong shallowing of the basin. This newly established shallower depth caused disappearance of globorotaliids from the environment. In the IIC biozone, the $\delta^{13} \mathrm{C}$ increased in Globigerina bulloides tests and slightly decreased in Uvigerinas. These $\delta^{13} \mathrm{C}$ contents in the IIC and IIB biozones are slightly similar regarding $\Delta \delta^{13} \mathrm{C}$ : $0.6 \%$ in IIC and $0.76 \%$ in IIB (Fig. 5). The causes of such $\delta^{13} \mathrm{C}$ content were the same as in the IIB interval, although they are pronounced stronger within the IIC biozone. The water column during IIC was much cooler, poorly stratified and shallower than any time before, thus the globorotaliids lost their habitat in the study area.

These circumstances sustained also during the younger Wielician (IID) biozone. The percentage of planktonic speci- 


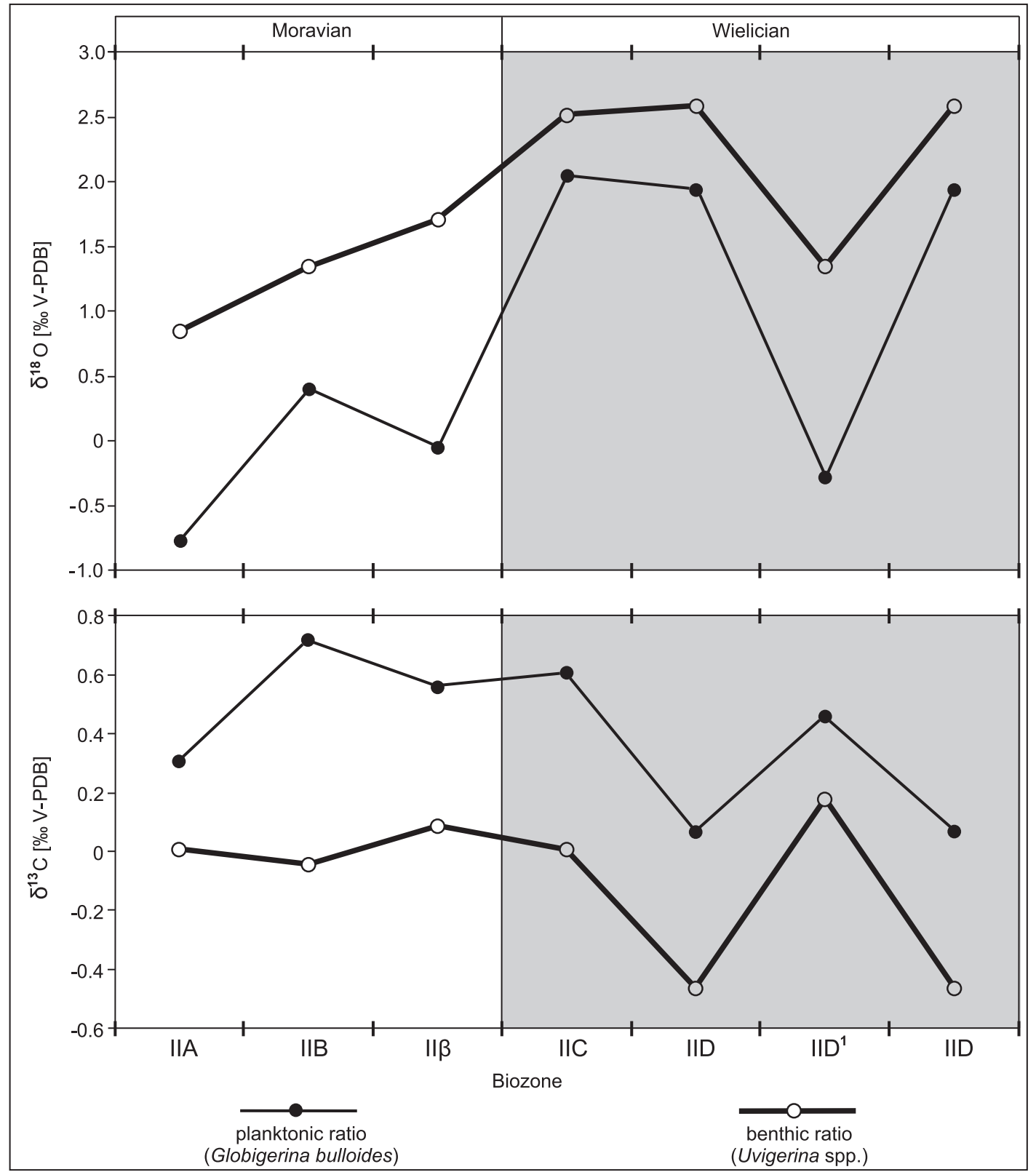

Fig. 5. Foraminiferal surface vs. bottom oxygen and carbon stable isotope range (median) calculated for the sub-evaporite Badenian

For more data see Table 5

mens in the foraminiferal assemblage diminished considerably, albeit there were the same cool-water taxa (Fig. 3 and Table 3). Thermal stratification of the water column, as can be referred based on $\delta^{18} \mathrm{O}$, remained similar to that of the IIC biozone (Fig. 4 and Table 4). Yet, the conspicuous change is in the ${ }^{13} \mathrm{C}$ content. The IID biozone is distinguished by a low content of ${ }^{13} \mathrm{C}$, as noted below (Fig. 5). The drop was $0.5 \%$ both in planktonic and in benthic foraminifers. The $\delta^{13} \mathrm{C}$ attains the lowermost values within the sub-evaporite Badenian: 0.07 and $-0.46 \%$, respectively (Fig. 5). It is characteristic that this drop in stable isotope values was observable both in the pelagic and benthic organisms of the basin. This is a fundamental difference between the previous biozones (IIB and IIC) showing a $\delta^{13} \mathrm{C}$ decrease only in the bottom waters, coupled with a $\delta^{13} \mathrm{C}$ increase in the surface water. The drop of $\delta^{13} \mathrm{C}$ within the whole water column during the IID was supposedly caused by the cessation of ${ }^{12} \mathrm{C}$ capture by phytoplankton. The above-discussed hydrography during the IID interval was interrupted by three influxes of fully marine waters from outside of the basin, always globorotaliid-bearing. The Globoconella bykovae species is present in two of these influxes: IID ${ }^{1}$ and IID ${ }^{3}$ (Fig. 3 and Table 3 ).

During the first influx (IID $\left.{ }^{1}\right)$ the P/B ratio is doubled compared to the non-flux IID period (Fig. 3 and Table 3). Warm-water taxa (Globoquadrina, Globigerinoides, Orbulina, and Globigerinella) account for $56 \%$ of the planktonic foraminiferal assemblage. Globorotaliids make up only a small proportion of the 
planktonic foraminifera with proportionally coiled Globoconella bykovae. The oxygen and carbon stable isotope data are scarce for zone IID ${ }^{1}$. Nevertheless, a difference between IID and IID ${ }^{1}$ is remarkable in both stable isotopes (Fig. 4 and Table 4). During this influx the $\Delta \delta^{18} \mathrm{O}$ value is higher (1.63\%) compared to that of IID $(0.63 \%)$, indicating a considerable increase in thermal stratification of the water column. The difference is also in the $\delta^{13} \mathrm{C}$ content - it is much higher in IID ${ }^{1}$ than in IID (Fig. 4 and Table 4). Noteworthy is that the $\delta^{13} \mathrm{C}$ increase is observable in both planktonic and benthic foraminifers (Fig. 5). This $\delta^{13} \mathrm{C}$ increase in the entire IID ${ }^{1}$ water column could be due to the return of $\delta^{12} \mathrm{C}$ capture by phytoplankton.

The Globoconella bykovae coiling is proportional in both IID 1 influx and the II $\beta$ biozone samples. Among the globorotaliids of IID ${ }^{1}$ the $J$. transsylvanica tests are rare, like in the II $\beta$ biozone. These two differ in the $\mathrm{P} / \mathrm{B}$ ratio, in spite of the similar set of warm-water symbiont-bearing planktonic foraminifera (Gonera, 2001). The difference between $\mathrm{IID}^{1}$ and $I I \beta$ samples (Gliwice 19, $173.5 \mathrm{~m}$; Pławniowice 1, $130 \mathrm{~m}$ and $133 \mathrm{~m}$ ) is in the $\delta^{18} \mathrm{O}$ and $\delta^{13} \mathrm{C}$ contents; nevertheless, these data are scarce within IID ${ }^{1}$ (Table 4; Figs. 4 and 5).

The samples of the second Globoconella bykovae-bearing influx contain sinistrally coiled specimens. The P/B ratio of this influx is the lowermost among all the deposits studied (Fig. 3 and Table 3). This scanty planktonic assemblage is dominated by cool-water symbiont-bearing globigerinas (G. bulloides, $G$. quinqueloba) and Globoconella bykovae ${ }^{\text {SINI. }}$. The assemblage comprises only single specimens of warm-water planktonic foraminifera: Globigerinoides and Orbulina. Apparently, the planktonic foraminiferal assemblages are less diverse than those recognized within the lower parts of the sub-evaporite Badenian. Unfortunately, there is no stable isotope data providing information on the hydrographic conditions of this event. Globoconella bykovae persisted proportionally coiled during the Moravian and sub-evaporitic Wielician and changed the coiling pattern to sinistral within this particular influx.

Before the Globoconella bykovae sINI-bearing influx, there has been proportionally coiled Globoconella minoritesta (G. minoritesta ${ }^{\text {PROP }}$ ) discovered within the IID ${ }^{2}$ influx (Fig. 2 and Table 2). The P/B ratio of this influx is $\sim 29 \%$ (Fig. 3 and Table 3 ). Cool-water symbiont-bearing taxa dominate in the planktonic foraminiferal assemblage (74\%). Globoconella minoritesta PROP is the only and common globorotaliid herein ( 21\%). Warm-water planktonic foraminifera (Globigerinoides and Orbulina) are rare in the assemblage. It is essential to mention here that before this particular influx, termed $\mathrm{IID}^{2}$, Globoconella minoritesta specimens do not occur in the older Badenian sediments (Appendix 1).

\section{THE GLOBOROTALIID DATA VERSUS THE ADJACENT SEAS OF THE PARATETHYS}

The three discovered influxes carrying outer marine water into the IID basin brought different globorotaliid species, as detected in some of the studied boreholes. In one of them (Gliwice 19) the depth distance between the IID ${ }^{1}$ and III ${ }^{2}$ influxes is merely $1.5 \mathrm{~m}$, thus the thickness of globorotaliid-bearing sediments must be rather thin compared to the Moravian globorotaliid levels (intervals). Thus, sampling density seems to be the pivotal factor to reveal the presence of the influxes. In the studied boreholes, the sampling interval in the Wielician deposits of the Skawina Fm. varies from $1.3 \mathrm{~m}$ (Gliwice 24) to $17.0 \mathrm{~m}$ (Pilchowice 10) and is $4.7 \pm 1.9 \mathrm{~m}$ in the remaining boreholes. This sampling coverage seems insufficient to find out a com- plete set of the influxes within particular sections (boreholes). The discovered globorotaliid events of the sub-evaporite Wielician seems to be a promising tool in high-resolution stratigraphy to position the Wielician evaporites in particular areas and to map this salinity crisis (Peryt, 2006).

In the studied material, the gypsum deposits of the Krzyżanowice Fm. are located either above IID ${ }^{1}$ (Pławniowice 1 borehole) or above IID (Bielszowice 7 and Gliwice 19 boreholes). The third influx (IID ${ }^{3}$ ) precedes the Krzyżanowice Fm. deposits in the Sumina and Żory 4 boreholes. It is present in one of the Breccia Member salt xenoliths of the Wieliczka halite deposit (sample no. 47 in Gonera et al., 2014). This youngest influx $\left(\right.$ IID $\left.^{3}\right)$ is located within the halite sedimentation area of the Carpathian Foredeep Wielician (Wieliczka Formation), delineated by Garlicki (1979) and Bukowski (2011). Thus, the halite sedimentation areas sustained longer under the terrigenous part of the Skawina Formation - it was up to the third globorotaliid influx. In halite-free areas, the Skawina Formation sedimentation terminated earlier, not persisting so long as in the halite sedimentation areas. The submitted globorotaliid data can serve as an indirect evidence on the not isochronous deposition of the Wielician salinity crisis facies. In the study area, it implies that the boundary of the Skawina and Krzyżanowice $\mathrm{Fm}$. is diachronous.

The Wielician globorotaliid events preceded the evaporite formation in the basinal part of the Polish Carpathian Foredeep Basin (this paper). In the coastal part of the basin, these events has been either absent (Gonera and Kulka, 1979; Peryt, 2013) or detected in one of the boreholes, but no data on coiling has been given (Łuczkowska, 1964).

The Globoconella bykovae and Jenkinsella mayeri globorotaliid interval of the Upper Silesia Basin (IIA biozone) is coeval to the Židlahovice parastratotype section described by Holcová and Demeny (2012) and Doláková et al. (2014). The globorotaliids younger than IIA biozone are barren in sediments of the Židlahovice boreholes. Described by Rupp and Hohenegger (2008), the globorotaliid association from the Badenian stratotype section is much similar to that of the $\| \beta$ biozone (i.e. the youngest globorotaliid level of the Moravian) and it followed the Badenian deposits considered by Doláková et al. (2014). The proposed Globorotalia transsylvanica Biozone (Filipescu and Filipescu, 2014-2015) is coeval with the IIB - at least as regards the dominant taxon. Examining the coiling pattern of Globorotalia bykovae, found by Báldi et al. (2017) below the Soltvadkert Trough evaporites of the Pannonian Basin, might be useful for intra-Paratethys stratigraphic correlation. In relation to the Wielician globorotaliid events described in this paper, the pivotal correlation aspect is the coiling preferences of the two globorotaliid peaks described by Kováčová and Hudáčková (2009) within the CPN 8 in the Slovak part of the Vienna Basin. It appears necessary to make a common practice to examine the secondary features of planktonic foraminifera tests like the coiling preference in the case of globorotaliid tests. It is believed that, if coiling direction counts become routine in planktonic foraminifera analyses in the Paratethys, the collected data can serve as a base for a higher-resolution stratigraphy.

\section{CALIBRATION OF THE STUDIED MATERIAL TO GLOBAL STRATIGRAPHY}

The GSSP (Global Stratigraphy Section and Point) data are considered to achieve the calibration of the studied material to global stratigraphy. According to Fornaciari et al. (1997) the top of the Langhian historical stratotype coincides with the First Oc- 
currence (FO) of Orbulina universa and the First Common Occurrence (FCO) of the nannoplankton Helicosphera walbersdorfensis. The morphospecies Orbulina universa is not mentioned from the Serravalian GSSP and no particular index taxon is recommended for this Point (Hilgen et al., 2009). In this stratotype section coccoliths Sphenolithus hetereomorphus Last (Common) Occurrence - L(C)O slightly postdates and Helicosphera walbersdorfensis (FCO) predates the Langhian/Serravalian boundary (Hilgen et al., 2009). Accordingly, the boundary is bracketed by these coccolith events within the Serravalian GSSP (Hilgen et al., 2009).

In the Paratethys, the youngest orbulinid is Orbulina suturalis (Cicha et al., 1998). Using the orbulinids datum index taxa (Blow, 1969) we are obliged to claim that the studied deposits are not younger than global Zone N9. After Lehotayova (1982), Dudziak and Łuczkowska (1991), Peryt et al. (1997), Peryt (1997), Chira (1999) and Garecka (2014), Sphenolithus heteromorphus specimens (without quantitative data) occur within the sub-evaporite Badenian. In the Upper Silesia Basin (Gliwice 17, Gliwice 19 and Gliwice 21 boreholes), Helicosphera walbersdorfensis is absent in the sub-evaporite Badenian (Peryt, 1997) or occurs only as single specimens east of the basin (Garecka, 2014). Helicosphera walbersdorfensis specimens occasionally occur within the Wielician gypsum deposits of the adjoining areas of the Upper Silesia Basin (Gaździcka, 1994; Peryt et al., 1997). Apparently, there are no calcareous index taxa (orbulinids, $H$. walbersdorfensis FCO) to tie the studied globorotaliid events to the global stratigraphy. Nevertheless, the (bio)stratigraphic events correlated to the Middle Miocene climate changes can be used to calibrate the discovered coiling preferences of the Paratethyan globorotaliid and globorotaliid intervals to the global stratigraphy. The references on Globigerina quinqueloba, Paragloborotalia siakensis, stable isotopes and radiometric data are here applied as the guiding tool to perform this stratigraphic calibration.

The Globigerina cf. quinqueloba Acme End (AE) discovered within the Blue Clay Formation $\sim 0.5 \mathrm{~m}$ above the Serravalian GSSP is dated at 13.74 Ma by Hilgen et al. (2009). In the studied Paratethyan deposits, the Globigerina quinqueloba first common occurrence (acme) is recorded as early as biozone II $\beta$ in three samples: $162.0 \mathrm{~m}$ in the Gliwice 24 borehole, and 310.0 and $300.0 \mathrm{~m}$ in the Sumina 2 borehole (Table 5). It accounts for 14,30 and $39 \%$ of the planktonic foraminiferal assemblage, respectively. As stated above, the II $\beta$ foraminiferal biozone represents an interval reflecting the disappearance of the Moravian ecosystem - a step-by-step elimination of taxa typical of the Moravian IIA and IIB assemblages (ecozones), before the new Wielician ecosystem assemblages of IIC and IID began. Globigerina quinqueloba is common in the IIC and IID assemblages of the Upper Silesia Basin (Gonera, 2001). In these deposits, G. quinqueloba with quantitatively significant peaks (up to $100 \%$ ) interfingers with Globigerina bulloides (Gonera, 2001). This pattern of the taxa distribution continues up to the evaporitic layers and even above it, within the Neobulimina longa Zone deposits (Table 1; Alexandrowicz, 1963; Łuczkowska, 1964; Gonera, 2001). Globigerina quinqueloba AE, which is positioned either at the base of the evaporites or at the top of the Neobulimina longa biozone deposits, is within the Wielician according to Gonera (1997).

Considering the Globigerina quinqueloba Acme as coeval in the Mediterranean and Paratethys, the contrary appears in regard to Globigerina quinqueloba AE versus Sphenolithus heteromorphus $\mathrm{L}(\mathrm{C}) \mathrm{O}$ in these two basins. In the Serravalian GSSP, Sphenolithus heteromorphus L(C)O, dated by Hilgen et al. (2009) at $13.654 \mathrm{Ma}$, occurs after G. cf. quinqueloba AE (Hilgen et al., 2009). In the studied Paratethys area, the events happened in a reversed sequence: G. quinqueloba AE occurs after the S. heteromorphus last occurrence (Gonera, 1997; Peryt, 1997). There is an absolute age of $13.62 \pm 0.10 \mathrm{Ma}$ available for the Neobulimina longa Zone deposits dated by the intercalated tuffite (Bukowski et al., 2010).

Application of the evolutionary datums of low-latitude fohsellids (Blow, 1969) or temperate-latitude globorotaliids (Berggren et al., 1995) in the Paratethys record is impossible. The obstacle is the Paratethyan globorotaliid taxonomy: Globoconella bykovae, Globoconella minoritesta and Jenkinsella transsylvanica under these names are essentially restricted to this area. The only exception is Jenkinsella mayeri,

Calibration of the globorotaliids (intervals, events, coiling patterns) to the global stratigraphy data

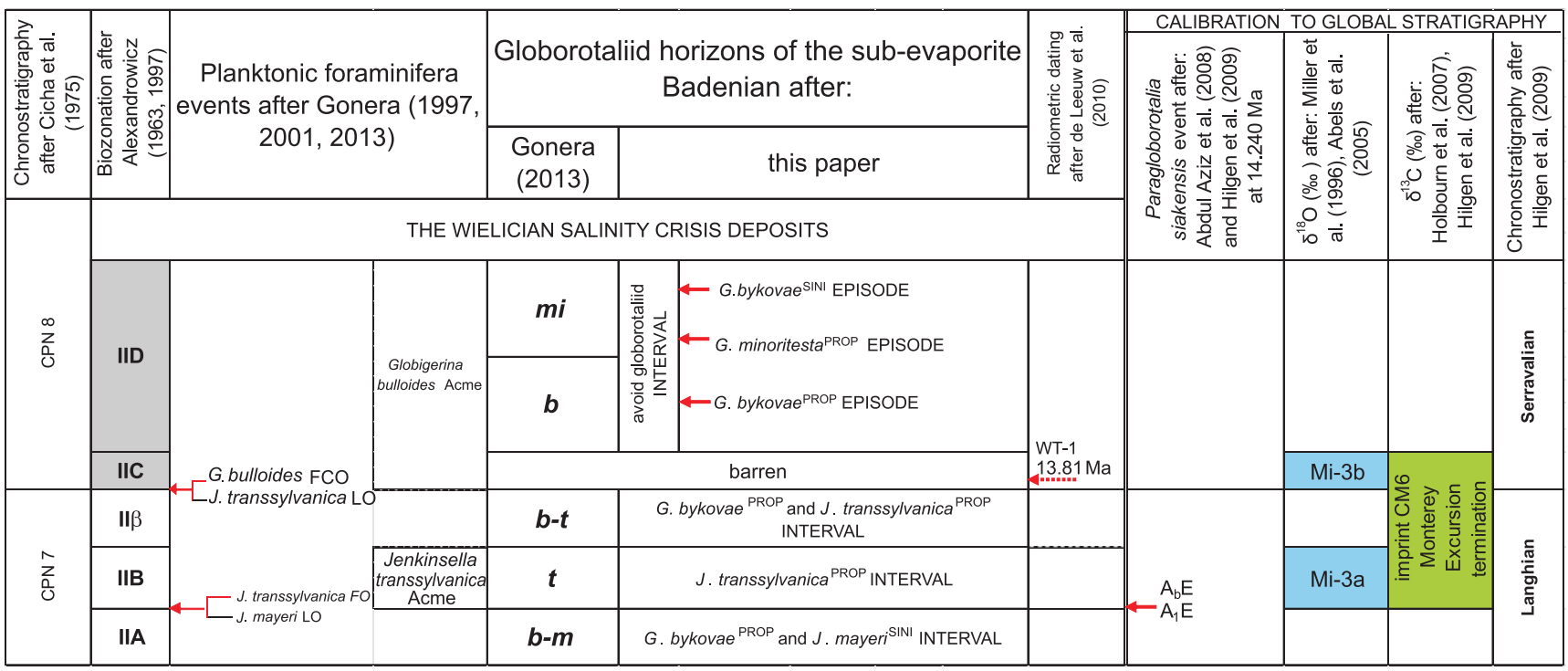


discussed by Gonera (2013), as a global-range taxon assigned to the Paratethyan Miocene. Here, Bolli and Saunders (1982) are followed in the resolution that Paragloborotalia siakensis is a junior synonym of Jenkinsella mayeri. The taxon coiling is proportional until N8, and then becomes sinistrally coiled up to its Middle Miocene extinction (Nagappa, 1957; Bolli and Saunders, 1985; Winter and Pearson, 2001). Abundant and sinistrally coiled J. mayeri within the Paratethys IIA biozone retreats at the top of this biozone (Fig. 2 and Table 2). The J. mayeri $\mathrm{AE}$ at the top of biozone IIA is prominent and the correlation of this event to the Mediterranean records is an important achievement.

The Paragloborotalia siakensis acmes have been recorded in many sections of the Mediterranean Miocene, but the events are not indexed in the unified manner (cf. Abdul Aziz et al., 2008; Hilgen et al., 2009). The Paragloborotalia siakensis $A_{1} E$ locates within the Langhian part of the Serravalian GSSP section and has been dated at 14.250 Ma (Hilgen et al., 2009). This is dated by Abdul Aziz et al. (2008) at $14.240 \mathrm{Ma}\left(\mathrm{A}_{b} \mathrm{E}\right)$ and is coeval with the Mi-3a cooling event. In the study area, the retreat of Jenkinsella mayeri ${ }^{\text {SNI }}$ is followed by J. transsylvanica PROP AB (Acme Beginning). This J. transsylvanica interval (IIB biozone) has been discovered as a cryptic cooling period based on the isotopic data of the studied sections (Gonera, 2013). Thus, there is a correspondence between the Paratethyan sinistral $J$. mayeri Acme End at the onset of the IIB biozone cryptic cooling and the Mediterranean Paragloborotalia siakensis $\mathrm{A}_{1} \mathrm{E}$ at the Mi-3a cooling. The Paratethyan sinistral $\mathrm{J}$. mayeri of the IIA biozone correlates well with the Mediterranean sinistrally coiled $J$. siakensis bioevent $A_{1} E$ alias $A_{b} E$. The $J$. transsylvanica FO, immediately followed by its acme, is coeval with the onset of the Moravian cryptic cooling interval (IIB biozone) in the studied material. The J. transsylvanica displays proportional coiling during this period (Table 2 and Fig. 2). Thus, both acmes of the Paratethyan (IIA biozone) sinistrally coiled J. mayeri and the Mediterranean J. siakensis $A_{b}$ end with the onset of the Mi-3a phase of the climate cooling dated by Hilgen et al. (2009) at 14.250 Ma, i.e. at the end of biozone N9.

Holbourn et al. (2007) also found higher $\delta^{18} \mathrm{O}$ values in the interval from 14.229 to $14.071 \mathrm{Ma}$. This is consistent with the Paratethys isotopic record: the IIB biozone displays cooler conditions compared to the IIA interval. The cryptic cooling interval in the Paratethys (IIB biozone) is followed by isotopically recorded (Globigerina bulloides $\delta^{18} \mathrm{O}$ ) warming of the $\| \beta$ biozone (Gonera, 2013). In the same section, Holbourn et al. (2007) demonstrated a warming recorded by $\delta^{18} \mathrm{O}$ between 14.025 and $13.874 \mathrm{Ma}$, i.e. until the end of the Langhian. The Paratethyan II $\beta$ biozone may correlate with this warming.

The IIC biozone displays cooling in both isotopic and foraminifera data (Durakiewicz et al., 1997; Gonera et al., 2000; Gonera, 2001; Gonera and Bukowski, 2012). This climate cooling at the beginning of the Wielician was formerly named Mi3 Event (Gonera, 2001; Bicchi et al., 2003). Considering the new developments in the area, it should be dated at the Mi-3b Event and coeval with the beginning of the Serravalian. This cooling is recorded upward continuously in the Wielician deposits, and interrupted by three globorotaliid influxes bringing some of the warm-water symbiont-bearing planktonic foraminifers into the basin (Fig. 3 and Table 3). These planktonic foraminifera are most numerous in $\mathrm{IID}^{1}$ and scarcer in the remaining two influxes $\left(I I D^{2}\right.$ and III ${ }^{3}$ ). Unfortunately, the oxygen and carbon stable isotope measurements of these influxes are non-systematic and sporadic, but they indicate the $\delta^{18} \mathrm{O}$ content lower than in the IID background samples (Fig. 4 and Table 4). The three warmer swings above Mi-3b had been also recorded by Holbourn et al. (2007) and dated at 13.705, 13.620 and $13.500 \mathrm{Ma}$, respectively. The remarkable correlation of these global events with the herein presented Paratethys globorotaliid influxes (IID ${ }^{1}$, IID $^{2}$ and IID ${ }^{3}$ ) cannot be ignored. The Paratethyan globorotaliid species associated with these three influxes are Globoconella bykovae ${ }^{\mathrm{PROP}}$, Globoconella minoritesta ${ }^{\mathrm{PROP}}$ and Globoconella bykovae ${ }^{\mathrm{SINI}}$.

The Serravalian GSSP is located by Hilgen et al. (2009) at the E3 alias Mi-3b Event of the $\delta^{18} \mathrm{O}$ record (Woodruff and Savin, 1991; Miller at al., 1991; Flower and Kennett, 1994; Abels et al., 2005). The strong swing to $\delta^{18} \mathrm{O}$ positive values at this Event is regarded as the termination of the Middle Miocene Climate Transition. This is the CM6 Event of the $\delta^{13} \mathrm{C}$ record and means the isotope maximum at the end of the Monterey carbon isotopic excursion (Miller et al., 1991; Jacobs et al., 1996). At the Serravalian GSSP, astronomically dated at 13.82 $\mathrm{Ma}$, the oxygen and carbon isotope records reveal shifts to heavier values as the signatures E3 alias Mi-3b and CM6, respectively (Hilgen et al., 2009).

In the basinal part of the Polish Carpathian Foredeep, the tuffite layer named WT- 1 is radiometrically dated at 13.81 $\pm 0.08 \mathrm{Ma}$ (de Leeuw et al., 2010). On the other hand, Dudziak and Łuczkowska (1991) stated that this tuff layer (WT-1) is located within siliciclastics of biozone IIC, i.e. within the lowermost part of the Uvigerina costai Zone (Table 5). Based on these data, we have a good reason to date the beginning of the Wielician in the Polish part of the Carpathian Foredeep just before $13.81 \pm 0.08 \mathrm{Ma}$, which is coeval to the onset of the Ice House age (Mi-3b event) after Hilgen et al. (2009). Thus, the IIB cryptic cooling in this area should be correlated with the upper Langhian Mi-3a Event (Table 5). In the database presented in Gonera and Bukowski (2012) and reconsidered in this paper, the Globigerina bulloides $\delta^{13} \mathrm{C}$ values of the IIB, II $\beta$ and IIC biozones characterize the interval from Mi-3a to Mi-3b (Fig. 5). These highest $\delta^{13} \mathrm{C}$ values embrace the Moravian/Wielician boundary in the studied material, displaying therein an imprint of the ending of the Monterey carbon isotope excursion.

The presented concept of the Langhian/Serravalian boundary within the Skawina Fm. is not discrepant with the Serravalian GSSP in regard to the Sphenolithus heteromorphus $\mathrm{L}(\mathrm{C}) \mathrm{O}$ and Discoaster floridanus LO resolutions after Hilgen et al. (2009). These index taxa are present in both the Moravian (biozones IIA, IIB and II $\beta$ ) and Wielician (IIC and IID biozones) sediments (Peryt, 1997). The range of Sphenolithus heteromorphus in the Upper Silesia Basin deposits justified the Serravalian GSSP positioning at the beginning of biozone IIC, i.e. at the base of the Wielician substage. The present paper supports and further confirms the opinion postulated by Rögl and Müller (1978), Łuczkowska (1998) and Hohenegger et al. (2014) on the Langhian/Serravalian boundary placed at the Orbulina suturalis/Uvigerina costai (alias Lagenidae/Spiroplectammina) Zone boundary in the Central Paratethys (Table 5). In the Polish part of the Paratethys, this boundary is found within the deposits of the Skawina Formation.

\section{CONCLUSIONS}

1. The Paratethyan Jenkinsella transsylvanica and Globoconella minoritesta, as the morphospecies appearing in the studied section, confirm Bolli's (1971) observation on the first exhibiting proportional coiling in early phylogeny of any taxa. 
2. The considered indices of coiling patterns vs. hydrography demonstrate that sinistrally coiled Jenkinsella mayeri (J. mayeri ${ }^{\mathrm{SINl}}$ ) is utterly sensitive to hydrographic changes. This is based on the observation that the taxon retreats from the basin when relatively warm pelagic waters became cooler at the IIA/IIB biozone boundary. On the other hand, proportionally coiled Globoconella bykovae (G. bykovae PROP) was found highly opportunistic to changing habitat conditions. This taxon showed proportional coiling throughout all the noticeable environmental changes through the Moravian and the sub-evaporite Wielician (IID ${ }^{1}$ ), and altered its coiling pattern to sinistral within the warmer water influx (IID ${ }^{3}$ ) just prior to the salinity crisis. Proportionally coiled Jenkinsella transsylvanica and Globoconella minoritesta are present under particular environmental circumstances (J. transsylvanica PROP during the IIB interval; G. minoritesta ${ }^{\text {PROP }}$ during the IID $^{2}$ influx) and retreat as the favourable environmental conditions vanished.

3. The correlation of Serravalian GSSP with the Paratethys Moravian/Wielician boundary has been achieved by the discovered globorotaliid bioevents coupled with the Middle Miocene climate changes. According to the Paratethys biostratigraphy, this GSSP corresponds to the Orbulina suturalis/Uvigerina costai (alias Lagenidae/Spiroplectammina) Zone boundary. In the study area, this boundary is coeval with the $I / / I I C$ biozone transition within the Skawina Fm.

4. The recognized globorotaliid events of IID ${ }^{1}, I I D^{2}$ and IID ${ }^{3}$ interposing the sub-evaporite Wielician records are pivotal to resolve the dating of the Wielician evaporites within adjoining areas of the Paratethys: are they isochronous, or non-isochronous?

5. The beginning of the cryptic cooling biozone (IIB) corresponds to the disappearance of sinistrally coiled Jenkinsella mayeri and the appearance of proportionally coiled $\mathrm{J}$. transsylvanica. The event is coeval with the Paragloborotalia siakensis $A_{b} E$ of the Mediterranean Middle Miocene sections and termed as Mi-3a, one of the cooling events of the Middle Miocene Climate Transition period. The disappearance of globorotaliids at the $I / \beta / I I C$ biozone boundary corresponds to a pronounced drop of temperature due to the Mi-3b cooling event with the advance of the Middle Miocene Ice House period.

6 . In the studied material, the highest ${ }^{13} \mathrm{C}$ content in Globigerina bulloides tests of the IIB, II $\beta$ and IIC biozones brackets the Moravian-Wielician boundary (CPN 7/CPN 8). This sign is the imprint of the termination of the Monterey carbon isotopic excursion attributed to the global Langhian/Serravalian boundary.

7. The evidences on the globorotaliid coiling pattern, presented in this paper, make us hope to develop a commonly used method of stratigraphic correlation between any regions within the Paratethys or outside.

Acknowledgements. Geological Quarterly reviewers, K. Báldi and anonymous reviewer, helped to improve the manuscript. Special thanks are to K. Báldi for fruitful discussions and suggestions. The author thanks S.W. Alexandrowicz and J. Wiewiórka for providing samples.

\section{REFERENCES}

Abdul Aziz, H., Di Stefano, A., Foresi, L.M., Hilgen, F.J., laccarino, S.M., Kuiper, K.F., Lirer, F., Salvatorini, G., Turco, E., 2008. Integrated stratigraphy of early Middle Miocene sediments from DSDP Leg 42A, Site 372 (eastern Mediterranean). Palaeogeography, Palaeoclimatology, Palaeoecology, 257: 123-138.

Abels, H.A., Hilgen, F.J., Kruk, R.W., Raffi, I., Turco, E., Zachariasse, W.J., 2005. Long-period orbital control on middle Miocene global cooling: Integrated stratigraphy and astronomical tuning of the Blue Clay Formation on Malta. Paleoceanography, 20: 1-17.

Alexandrowicz, S.W., 1963. Stratigraphy of the Miocene deposits in the Upper Silesian basin (in Polish with English summary). Prace Instytutu Geologicznego, 39.

Alexandrowicz, S.W., 1997. Lithostratigraphy of the Miocene deposits in the Gliwice area (Upper Silesia, Poland). Bulletin of the Polish Academy of Sciences, Earth Sciences, 45: 167-179.

Alexandrowicz, S.W., Garlicki, A., Rutkowski, J., 1982. Podstawowe jednostki litostratygraficzne miocenu zapadliska przedkarpackiego. Kwartalnik Geologiczny, 26: 470-471.

Báldi, K., 2006. Paleoceanography and climate of the Badenian (Middle Miocene, 16.4-13.0 Ma) in the central Paratethys based on foraminifera and stable isotope $\left(\delta^{18} \mathrm{O}\right.$ and $\left.\delta^{13} \mathrm{C}\right)$ evidence. International Journal of Earth Sciences, 95: 119-142.

Báldi, K., Velledits, F., Ćorić, S., Lemberkovics, V., Lőrincz, K., Shevelev, M., 2017. Discovery of the Badenian evaporites inside the Carpathian Arc: implications for global climate change and Paratethys salinity. Geologica Carpathica, 68: 193-206.

Bandy, O.L., 1960. The geologic significance of coiling ratios in the foraminifer Globigerina pachyderma (Ehrenberg). Journal of Paleontology, 34: 671-681.

Bandy, O.L., 1972. Variations in Globigerina bulloides d'Orbigny as indices of water masses. Antarctic Journal, 7: 194-195.
Bé, A.W.H., 1977. An ecological, zoogeographic and taxonomic review of recent planktonic foraminifera. In: Oceanic Micropaleontology (ed. A.T.S. Ramsay): 1-100. Academic Press, London.

Bé, A.W.H., Hutson, W.H., 1977. Ecology of planktonic foraminifera and biogeographic patterns of life and fossil assemblages in the Indian Ocean. Micropaleontology, 23: 369-414.

Bé, A.W.H., Tolderlund, D.S., 1971. Distribution and ecology of living planktonic foraminifera in surface waters of the Atlantic and Indian Oceans. In: Micropaleontology of Oceans (eds. B.M. Funnel and W.R. Riedel): 105-149. The Cambridge University Press, Cambridge.

Berggren, W.A., Kent, D.V., Swisser, III C.C., Aubry, M.P., 1995. A revised Cenozoic geochronology and chronostratigraphy. SEPM Special Publication, 54: 129-212.

Bicchi, E., Ferrero, E., Gonera, M., 2003. Paleoclimatic interpretation based on Middle Miocene planktonic foraminifera: the Silesia Basin (Paratethys) and Monferrato (Tethys) record. Palaeogeography, Palaeoclimatology, Palaeoecology, 196: 265-303.

Blow, W.H., 1969. Late Middle Eocene to Recent planktonic foraminiferal biostratigraphy. Proceedings First International Conference on Planktonic Microfossils, Genova, 1: 199-422.

Bolli, H.M., 1950. The direction of coiling in the evolution of some Globorotaliidae. Contributions from the Cushman Foundation for Foraminiferal Research, 1: 82-89.

Bolli, H.M., 1971. The direction of coiling in planktonic foraminifera. In: Micropaleontology of Oceans. (eds. B.M. Funnel and W.R. Riedel): 639-648. The Cambridge University Press, Cambridge.

Bolli, H.M., Saunders, J.B., 1982. Globorotalia mayeri and its relationship to Globorotalia siakensis and Globorotalia continuosa. Journal of Foraminiferal Research, 12: 39-59. 
Bolli, H.M., Saunders, J.B., 1985. Oligocene to Holocene low latitude planktic foraminifera. In: Planktonic Stratigraphy (eds. H.M. Bolli, J.B. Saunders and K. Perch-Nielsen): 155-261. The Cambridge University Press, Cambridge.

Boltovskoy, E., 1962. Planktonic foraminifera as indicators of different water masses in the South Atlantic. Micropaleontology, 8: 403-408.

Boltovskoy, E., 1973. Note on the determination of absolute surface water paleotemperature by means of the foraminifer Globigerina bulloides d'Orbigny. Paläontologische Zeitschrift, 47: 152-155.

Boltovskoy, E., Wright, R., 1976. Recent Foraminifera. Junk, The Haque.

Boltovskoy, E., Boltovskoy, D., Correa, N., Brandini, F., 1996. Planktonic foraminifera from the southwestern $\left(30^{\circ}-60^{\circ} \mathrm{S}\right)$ : species-specific patterns in the upper $50 \mathrm{~m}$. Marine Micropaleontology, 28: 53-72.

Brunner, G.J., Kroon, D., 1988. Genetically controlled planktonic foraminiferal coiling ratios as tracers of past ocean dynamics. In: Planktonic Foraminifers as Tracers of Ocean-Climate History (eds. G.J. Brunner and D. Kroon): 131-147. Free University Press, Amsterdam.

Bukowski, K., 2011. Badenian saline sedimentation between Rybnik and Dębica based on geochemical, isotopic and radiometric research (in Polish with English summary). Dissertations Monographs, 236.

Bukowski, K., de Leeuw, A., Gonera, M., Kuiper, K.F., Krzywiec, P., Peryt, D., 2010. Badenian tuffite levels within the Carpathian orogenic front (Gdów-Bochnia area, Southern Poland): radio-isotopic dating and stratigraphic position. Geological Quarterly, 54 (4): 449-464.

Chira, C., 1999. Middle Miocene calcareous nannoplankton from the western Transylvanian Basin, Romania: biostratigraphy, taxonomy and palaeoecology. Studia Univ. BabeşBolyai ClujNapoca, Geol.-Geogr., 44: 3-75.

Cicha, I., Čtyroká, J., Jiřiček, R., Zapletalová, I., 1975. Principal biozones of the Late Tertiary in East Alps and West Carpathians. In: Biozonal division of the Upper Tertiary basins of the Eastern Alps and West Carpathians, IUGS Proceedings of the VI. Congress, Bratislava (ed. I. Cicha): 19-34

Cicha, I., Rögl, F., Rupp, Ch., Čtyroká, J., 1998. Oligocene-Miocene foraminifera of the Central Paratethys. Abhandlungen der Senckenbergischen Naturforschenden Gesellschaft, 549: 1-325.

Cita, M.B., Blow, W.H., 1969. The biostratigraphy of the Langhian, Serravalian and Tortonian stages in the type-sections in Italy. Rivista Italiana de Paleontologia, 75: 549-603.

de Leeuw, A., Bukowski, K., Krijgsman, W., Kuiper, K.F., 2010. Age of the Badenian salinity crisis; impact of Miocene climate variability on the circum-Mediterranean region. Geology, 38: 715-718.

Doláková, N., Holcová, K., Nehyba, S., Hladilová S., Brzobohatý, R., Zágoršek K., Hrabkovský, J., Seko, M., Utescher, T., 2014. The Badenian parastratotype at Židlachovice from the perspective of the multiproxy study. Neues Jahrbuch für Geologie und Paläontologie Abhandlungen, 271: 169-201.

Dudziak, J., Łuczkowska, E., 1991. Biostratigraphic correlation of foraminiferal and calcareous nannoplankton zones - Middle Badenian (Miocene), southern Poland. Bulletin of the Polish Academy of Sciences, Earth Sciences, 39: 199-214.

Durakiewicz, T., Gonera, M., Peryt, T.M., 1997. Oxygen and carbon isotopic changes in the Middle Miocene (Badenian) foraminifera of the Gliwice area (SW Poland). Bulletin of the Polish Academy of Sciences, Earth Sciences, 45: 145-156.

Eisenach, A.R., Kelly, D.C., 2006. Coiling preferences and evolution in the middle Miocene Fohsella chronocline. Marine Micropaleontology, 60: 243-257.

Ericson, D.B., 1959. Coiling direction of Globigerina pachyderma as climatic index. Science, 130: 219-220.

Ericson, D.B., Wollin, G., Wolin, J., 1954. Coiling dorection of Globorotalia truncatulinoides in deep-sea cores. Deep-Sea Research, 2: 152-158.
Ericson, D.B., Ewing, M., Wollin, G., Heezen, B.C., 1961. Atlantic deep-sea sediment cores. GSA Bulletin, 72: 104-125.

Filipescu, R., Filipescu, S., 2014-2015. New data on the Early-Middle Badenian transition in the NW Transylvanian Basin (Romania) revealed by the planktonic foraminiferal assemblages. Studia UBB Geologia, 59: 39-44.

Flower, B.P., Kennett, J.P., 1994. The middle Miocene climatic transition: East Antarctic ice sheet development, deep ocean circulation and global carbon cycling. Palaeogeography, Palaeoclimatology, Palaeoecology, 108: 537-555.

Foresi, L.C., Verducci, M., Baldassini, N., Lirer, F., Mazzei, R., Gianfranco, S., Ferraro, L., Da Prato, S., 2011. Integrated stratigraphy of St. Peter's Pool section (Malta): new age for the Upper Globigerina Limestone member and progress towards the Langhian GSSP. Stratigraphy, 8: 125-143.

Fornaciari, E., Rio, D., Ghibaudo, G., Massari, F., laccarino, S., 1997. Calcareous plankton biostratigraphy of the Serravallian (Middle Miocene) stratotype section (Piedmont Tertiary Basin, NW Italy). Memoire di Scienze Geologiche, 49: 127-144.

Fujiwara, O., Yanagisawa, Y., Irizuki, T., Shimamoto, M., Hayashi, H., Danhara, T., Fuse, K., Iwano, H., 2008. Chronological data for the Middle Miocene to Pliocene sequence around the southwestern Sandai Plain, with special reference to the uplift history of the Ou Backbone Range. Bulletin of the Geological Survey of Japan, 59: 423-438.

Garecka, M., 2014. Biostratigraphy of the Middle Miocene deposits in the Trojanowice 2 borehole based on calcareous nannoplankton investigation (in Polish with English summary). Biuletyn Państwowego Instytutu Geologicznego, 459: 33-44.

Garlicki, A., 1979. Sedimentation of Miocene salts in Poland (in Polish with English summary). Prace Geologiczne, 119.

Garlicki, A., 1994. Formal lithostratigraphic units of the Miocene Wieliczka Formation (in Polish). Przegląd Geologiczny, 42: 26-28.

Gaździcka, E., 1994. Nannoplankton stratigraphy of the Miocene deposits in Tarnobrzeg area (northeastern part of the Carpathian Foredeep). Geological Quarterly, 38 (3): 553-570.

Gonera, M., 1997. Miocene foraminiferal assemblages in the Gliwice area (Upper Silesia, Poland). Bulletin of the Polish Academy of Sciences, Earth Sciences, 45: 97-105

Gonera, M., 2001. Foraminiferida and paleoenvironment of the Badenian formations (Middle Miocene) in the Upper Silesia (Poland) (in Polish with English summary). Studia Naturae, 48

Gonera, M., 2013. Globorotaliid intervals of the sub-evaporite Badenian (Middle Miocene) in the Upper Silesia Basin (Central Paratethys, Poland). Geological Quarterly, 57 (4): 757-767.

Gonera, M., Bukowski, K., 2012. Isotopic events in the Early/Middle Badenian (Miocene) of the Upper Silesia Basin (Central Paratethys). Geological Quarterly, 56: 561-568.

Gonera, M., Kulka, A., 1979. The age and stratigraphic position of the Heterostegina sands, Miechów and Racławice region (in Polish with English summary). Zeszyty Naukowe AGH. Geologia, 5 (3): 65-71.

Gonera, M., Peryt, T.M., Durakiewicz, T., 2000. Biostratigraphical and paleoenvironmental implications of isotopic studies $\left({ }^{18} \mathrm{O}\right.$, ${ }^{13} \mathrm{C}$ ) of the middle Miocene (Badenian) foraminifers in the Central Paratethys. Terra Nova, 12: 231-238.

Gonera, M., Peryt, T.M., Durakiewicz, T., 2003. Coiling direction in Globigerina bulloides of Middle Miocene age. Journal of Micropaleontology, 22: 141-146.

Gonera, M., Wiewiórka, J., d’Obyrn, K., Bukowski, K., 2014. Wielician (Middle Badenian) foraminifers from the stratotype area - Wieliczka Salt Mine, Poland (Paratethys, Middle Miocene) Geological Quarterly, 58 (3): 427-438.

Hilgen, F.J., Abels, H.A., laccarino, S., Krijgsman, W., Raffi, I., Sprovieri, R., Turco, E., Zachariasse, W.J., 2009. The Global Stratotype Section and Point (GSSP) of the Serravallian Stage (Middle Miocene). Episodes, 32: 152-166.

Hofker, J., 1972. Is the direction of coiling in the early stages of an evolution of planktonic foraminifera at random? (50\% right and $50 \%$ left). Revista Espańola de Micropaleontología, 4: 11-17. 
Hohenegger, J., Coric, S., Wagreich, M., 2014. Timing of the Middle Miocene Badenian stage of the Central Paratethys. Geologica Carpathica, 65: 55-66.

Holbourn, A., Kuhnt, W., Schulz, M., Flores, J.-A., Andersen, N., 2007. Orbitally-paced climate evolution during the middle Miocene "Monterey" carbon-isotope excursion. Earth and Planetary Science Letters, 261: 534-550.

Holcová, K., Demeny, A., 2012. The oxygen and carbon isotopic composition of Langhian foraminiferal tests as a paleoecological proxy in a marginal part of the Carpathian Foredeep (Czech Republic). Geologica Carpathica, 63: 121-137.

Hüsing, S.K., Cascella, A., Hilgen, F.J., Krijgsman, W., Kuiper, K.F., Turco, E., Wilson, W., 2010. Astrochronology of the Mediterranean Langhian between 15.29 and 14.17 Ma. Earth and Planetary Science Letters, 290: 254-269.

laccarino, S., 1985. Mediterranean Miocene and Pliocene planktic foraminifera. In: Planktonic Stratigraphy (eds. H.M. Bolli, J.B. Saunders and K. Perch-Nielsen): 283-314. The Cambridge University Press, Cambridge.

Jacobs, E., Weissert, H., Shields, G., 1996. The Monterey event in the Mediterranean: a record from shelf sediments of Malta. Paleoceanography, 11: 717-728.

Jenkins, D.G., 1967. Recent distribution, origin, and coiling ratio changes in Globorotalia pachydrma (Ehrenberg). Micropaleontology, 13: 195-203.

Kennett, J.P., 1976. Phenotypic Variation in some recent and Late Cenozoic planktonic foraminifera. In: Foraminifera (eds. R.H. Hedley and C.G. Adams), 2: 111-170. Academic Press, London.

Kováčová, P., Hudáčková, N., 2009. Late Badenian foraminifers from the Vienna Basin (Central Paratethys): stable isotope study and paleoecological implications. Geologica Carpathica, 60: 59-70.

Kucera, M., Kennett, J.P., 2002. Causes and consequences of a middle Pleistocene origin of the modern planktonic foraminifer Neogloboquadrina pachyderma sinistral. Geology, 30: 539-542.

Lehotayova, R., 1982. Miocene nannoplankton zones in West Carpathians. Zapadne Karpaty Seria Paleontologia, 8: 91-100.

Lidz, B., 1972. Globorotalia crassaformis morphotype variation in Atlantic and Caribbean deep-sea cores. Micropaleontology, 18: 194-211.

Lirer, F., laccarino, S., 2005. Integrated stratigraphy (cyclostratigraphy and biochronology) of late Middle Miocene deposits in the Mediterranean area and comparison with the North and Equatorial Atlantic oceans: synthesis of the major results. Terra Nova, 17: 338-349.

Little, M.G., Schneider, R.R., Kroon, D., Price, B., Bickert, T., Wefer, G., 1997. Rapid paleoceanographic changes in the Benguela Upwelling System for the last 160,000 years as indicated by abundances of planktonic foraminifera. Palaeogeography, Palaeoclimatology, Palaeoecology, 130: 135-161.

Łuczkowska, E., 1964. The micropaleontological stratigraphy of the Miocene in the region of Tarnobrzeg-Chmielnik (in Polish with English summary). Prace Geologiczne, 20.

Łuczkowska, E., 1998. Marine Miocene deposits of the Paratethys in Poland. Abhandlungen Senckenbergischen Naturforschenden Gesellschaft, 549: 29-34.

Majewski, W., 2010. Planktonic foraminiferal response to Middle Miocene cooling in the Southern Ocean (ODP Site 747, Kerguelen Plateau). Acta Palaeontologica Polonica, 55: 541-560.

Malmgren, B., Kennett, J.P., 1976. Biometric analysis of phenotypic variation in Recent Globigerina bulloides d'Orbigny in the southern Indian Ocean. Marine Micropaleontology, 1: 3-25.

Miller, K.G., Mountain, G.S., the Leg 150 Shipboard Party, Members of the New Jersey Coastal Plain Drilling Project, 1996. Drilling and dating New Jersey Oligocene-Miocene sequences: ice volume, global sea level, and Exxon records. Science, 271: 1092-1095.

Miller, K.G., Wright, J.D., Fairbanks, R.G., 1991. Unlocking the Ice House: Oligocene-Miocene oxygen isotopes, eustacy and marginal erosion. Journal of Geophysical Research, 96: 6829-6848.
Murray, J.W., 1976. A method of determining proximity of marginal seas to an ocean. Marine Geology, 22: 103-119.

Nagappa, Y., 1957. Directionof coiling in Globorotalia as an aid in correlation. Micropaleontology, 3: 393-398.

Naidu, P.V., Malmgren, B.A., 1996. Relationship between Late Quaternary upwelling history and coiling properties of Neogloboquadrina pachyderma and Globigerina bulloides in the Arabian Sea. Journal of Foraminiferal Research, 26: 64-70.

Olsson, R.K., 1970. Paleocene planktonic foraminiferal biostratigraphy and paleozoogeography of new Jersey. Journal of Paleontology, 44: 589-597.

Oszczypko, N., Krzywiec, P., Popadyuk, I., Peryt, T.M., 2006. Carpathian Foredeep Basin (Poland and Ukraine): its sedimentary, structural, and geodynamic evolution. AAPG Memoir, 84: 293-350.

Papp, A., Cicha, I., Seneš, J., 1978a. Gliederung des Badenian, Faunenzonen und Unterstufen. In: Chronostratigraphie und Neostratotypen: Miozän der Zentralen Paratethys, 6 (ed. E. Brestenská): 49-52 $\mathrm{M}_{4}$ Badenian (Moravien, Wielicien, Kosovien). VEDA SAV, Bratislava.

Peryt, D., 1997. Calcareous nannoplankton stratigraphy of the Middle Miocene in the Gliwice area (Upper Silesia, Poland). Bulletin of the Polish Academy of Sciences, Earth Sciences, 45: 119-131.

Peryt, D., 2013. Foraminiferal record of the Middle Miocene climate transition prior to the Badenian salinity crisis in the Polish Carpathian Foredeep Basin (central Paratethys). Geological Quarterly, 57 (1): 141-164.

Peryt, T.M., 2006. The beginning, development and termination of the Middle Miocene Badenian salinity crisis in Central Paratethys. Sedimentary Geology, 188-189: 379-396.

Peryt, T.M., Karoli, S., Peryt, D., Petrichenko, O.I., Gedl, P., Narkiewicz, W., Ďurkovičová, J., Dobieszyńska, Z., 1997. Westernmost occurrence of the Middle Miocene Badenian gypsum in central Paratethys (Kobeřice, Moravia, Czech Republic). Slovak Geological Magazine, 3: 105-120.

Peryt, T.M., Buła, Z., Hałas, S., Olszewska, B., Pluta, I., Słodkowska, B., 2005. Non-marine evaporites in the Lower Miocene of Upper Silesia (Carpathian Foreland Basin, Poland). Geologica Carpathica, 56: 327-336.

Pfuhl, H.A., Shackleton, N.J., 2004. Changes in coiling direction, habitat depth and abundances in two menardellid species. Marine Micropaleontology, 50: 3-20.

Popescu, Gh., Brotea, D.,1994. Evolutionof the Transylvanian foraminiferal assemblages during Late Oligocene and Middle Miocene. The Miocene from the Transylvanian Basin, Romania, Editura Carpatica Cluj-Napoca: 119-124.

Reynolds, L.A., Thunell, R.C., 1986. Seasonal production and morphologic variation of Neogloboquadrina pachyderma (Ehrenberg) in the northeast Pacific. Micropaleontology, 32: $1-18$.

Rio, D., Cita, M.B., laccarino, S., Gelati, R., Gnaccolini, M., 1997 Langhian, Serravalian, and Tortonian historical stratotypes. In: Miocene Stratigraphy: an Integrated Approach (eds. A. Montanari, G.S. Odin and R. Coccioni): 57-87. Elsevier.

Rögl, F., 1985. Late Oligocene and Miocene planktic foraminifera of the Central Paratethys. In: Planktonic Stratigraphy (eds. H.M. Bolli, J.B. Saunders and K. Perch-Nielsen): 315-328. The Cambridge University Press, Cambridge.

Rögl, F., 1998. Palaeogeographic considerations for Mediterranean and Paratethys seaways (Oligocene to Miocene). Annalen des Naturhistorischen Museums in Wien, 99A: 279-310.

Rögl, F., Müller, C., 1978. Middle Miocene salinity crisis and paleogeography of the Paratethys (Middle and Eastern Europe). Initial Reports of the Deep Sea Drilling Project, Volume Leg 42A: 985-990.

Rögl, F., Steininger, F.F., 1984. Neogene Paratethys, Mediterranean and Indo-Pacific seaways. In: Fossils and Climate (ed. P. Branchley): 171-200. Wiley.

Rupp, Ch., Hohenegger, J., 2008. Paleoecology of planktonic foraminifera from the Baden-Sooss section (Middle Miocene, 
Badenian, Vienna basin, Austria). Geologica Carpathica, 59: 425-445.

Saito, T., Maiya, S., 1973. Planktonic foraminifera of the Nishikurosawa Formation, Northeast Honsiu, Japan. Translations and Proceedings of the Paleontological Society of Japan, New Series, 91: 113-125.

Schiebel, R., Hemleben, Ch., 2005. Modern planktic foraminifera. Paläontologische Zeitschrift, 79: 135-148.

Scott, G.H., Bishop, S., Burt, B.J., 1990. Guide to some Neogene Globorotalid (Foraminiferida) from New Zealand. New Zealand Geological Survey Paleontological Bulletin, 61: 1-135.

Seneš, J., 1971. Korrelation des Miozäns der Zentralen Paratethys (Stand 1970). Geologicky Zbornik, 22: 3-9.

Simstich, J., Sarnthein, M., Erlenkeuser, H., 2003. Paired $\delta^{18} \mathrm{O}$ signals of Neogloboquadrina pachyderma (s) and Turborotalita quinqueloba show thermal stratification structure in Nordic Seas. Marine Micropaleontology, 48: 107-125.

Steininger, F.F., Seneš, J., Kleeman, K., Rögl, F. eds., 1985. Neogene of the Mediterranean Tethys and Paratethys. Stratigraphic correlation tables and sediment distribution maps. Institute of Paleontology, University of Vienna.

Szczechura, J., 1982. Middle Miocene foraminiferal biochronology and ecology of SE Poland. Acta Palaeontologica Polonica, 27: $125-130$.
Thiede, J., 1971. Variations in coiling ratios of Holocene planktonic foraminifera. Deep-Sea Research, 18: 823-831.

Tolderlund, D.S., Bé, A.W.H., 1971. Seasonal distribution of planktonic foraminifera in the western North Atlantic. Micropaleontology, 17: 297-329.

Vašiček, M., 1953. Changes in the ratio of sinistral and dextral individuals of the foraminifer Globorotalia scitula (Brady), and their use in stratigraphy. Sbornik Ustředniho Ustavu Geologíckoho Instituta. Oddil Paleontologicki, 20: 401-420.

Vella, P., 1974. Coiling ratios of Neogloboquadrina pachyderma (Ehrenberg): variations in different size fractions. GSA Bulletin, 85: 1421-1424.

Wilke, I., Meggers, H., Bickert, T., 2009. Depth habitats and seasonal distribution of recent planktic foraminifers in the Canary Islands region $\left(290^{\circ}\right)$ based on oxygen isotopes. Deep-Sea Research I, 56: 89-106.

Winter, C.J., Pearson, P.N., 2001. Coiling direction in some Miocene planktonic foraminifera. Journal of Micropaleontology, 20: 29-30.

Woodruff, F., Savin S.M., 1991. Mid-Miocene isotope stratigraphy in the deep sea: high resolution correlations, paleoclimatic cycles, and sediments preservation. Paleoceanography, 6: 755-806. 